\title{
Ruthenium(II) Picolyl-NHC Complexes: Synthesis, Characterization, and Catalytic Activity in Amine $\mathrm{N}$-alkylation and Transfer Hydrogenation Reactions
}

\author{
Francys E. Fernández, M. Carmen Puerta,* and Pedro Valerga* \\ Departamento de Ciencia de los Materiales e Ingeniería Metalúrgica y Química Inorgánica, Facultad de Ciencias, \\ Universidad de Cádiz, 11510 Puerto Real, Cádiz, Spain
}

\section{Supporting Information}

ABSTRACT: Ruthenium(II) p-cymene complexes with picolylfunctionalized N-heterocyclic carbenes $\left[\left(\eta^{6}-p\right.\right.$-cymene $\left.) \mathrm{Ru}(\mathrm{L})(\mathrm{Cl})\right]$ $\left[\mathrm{PF}_{6}\right]$ (L = 3-methyl-1-(2-picolyl)imidazol-2-ylidene (1a), 3isopropyl-1-(2-picolyl)imidazol-2-ylidene (1b), 3,4,5-trimethyl1-(2-picolyl)imidazol-2-ylidene (1c), 3-mesityl-1-(2-picolyl)imidazol-2-ylidene (1d), 3-methyl-1-(2-picolyl)benzoimidazol2-ylidene (1e), 3-methyl-1-(2-picolyl)-4,5-dichloroimidazol-2ylidene (1f), 3-phenyl-1-(2-picolyl)imidazol-2-ylidene (1g)) have been synthesized and characterized. Compounds $1 \mathbf{a}-\mathbf{g}$ were recrystallized, and X-ray crystal structures are reported for $\mathbf{1 a , f}$. Furthermore, compounds $\mathbf{1 a}-\mathbf{f}$ show catalytic activity in transfer hydrogenation of ketones and N-alkylation of amines. Notably, complexes $\mathbf{1 a}, \mathbf{c}, \mathbf{f}$ were found to be very efficient and versatile catalysts toward transfer hydrogenation of a wide range of ketones and imines in addition to $\mathrm{N}$-alkylation of several amines.

\section{INTRODUCTION}

Amines and alcohols are key building blocks in organic synthesis. The use of catalytic transformations for the generation of those products is one of the means toward sustainable industrial processes. Transfer hydrogenation reactions of $\mathrm{C}=\mathrm{O}$ and $\mathrm{C}=\mathrm{N}$ groups is a source of amines and alcohols using transition-metal complexes as catalysts. This reaction has been widely studied and continues to attract special interest, given its simplicity and readily availability of substrates. ${ }^{1}$ The alkylation reaction of amines is usually completed using alkyl halides. However, the procedure frequently leads to overalkylation and, considering the necessity for environmentally friendly processes, the high toxicity of many alkylating agents is a major disadvantage. ${ }^{2}$ The use of alcohols as alkylating agents for amines has proven to be less efficient, given their low electrophilicity. Nevertheless, the use of transitionmetal complexes as catalysts via a borrowing hydrogen mechanism (Scheme 1) makes the $\mathrm{N}$-alkylation using alcohols a potentially less hazardous and more atom-economical process. ${ }^{3}$

Several transition-metal complexes have been used as catalysts in transfer hydrogenation and $\mathrm{N}$-alkylation reactions. Recently, N-heterocyclic carbenes (NHCs) have been widely used in organometallic chemistry as an alternative to wellknown phosphine ligands for the synthesis of homogeneous catalysts. ${ }^{4}$ Particularly, NHCs functionalized with an additional donor group have become an important group of ligands due to the potential hemilability of the new donor group, capable of reversible dissociation from the metal center. ${ }^{5}$ Several donor groups such as phosphine, ${ }^{6}$ pyrimidine, ${ }^{7}$ ether, ${ }^{8}$ thioether, ${ }^{9}$ carboxylate, ${ }^{10}$ indenyl, ${ }^{11}$ oxazoline, ${ }^{12}$ and pyridine ${ }^{13}$ have been
Scheme 1. Representative Reaction Using the Borrowing Hydrogen Mechanism

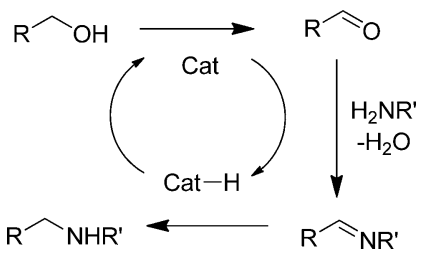

reported to functionalize NHCs. Ligands bearing nitrogen donors have attracted a great deal of attention. Particularly, metal complexes of $\mathrm{Ir},{ }^{14} \mathrm{Ag},{ }^{15} \mathrm{Pd},{ }^{16} \mathrm{Ru},{ }^{17}$ and $\mathrm{Ni}^{18}$ containing pyridine-functionalized NHCs have been synthesized. Among nitrogen donors, picoline has been used to generate $N$-picolylNHC ligands which can be easily synthesized with different substitution patterns on the picoline ring and the NHC. ${ }^{19}$

NHC complexes of iridium, ${ }^{7 b, 20}$ rhodium, ${ }^{21}$ and ruthenium ${ }^{22}$ have demonstrated good activity in transfer hydrogenation reactions, mainly showing significant applications in asymmetric reductions $^{23}$ and racemization of chiral alcohols. ${ }^{24}$ Recently, we have reported the synthesis of $\mathrm{Cp}^{*}$ ruthenium complexes $\left(\mathrm{Cp}^{*}=\right.$ pentamethylcyclopentadienyl $)$ bearing picolyl-NHCs, which showed excellent catalytic activity in transfer hydrogenation reactions of $\mathrm{C}=\mathrm{O}$ and $\mathrm{C}=\mathrm{N}$ groups (Figure 1 ). ${ }^{25}$ In contrast, to the best of our knowledge only Crabtree and co-workers have described the use of chelating NHC complexes

Received: July 23, 2012

Published: September 18, 2012 


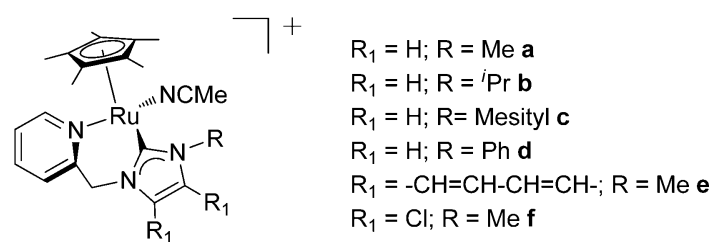

Figure 1. $\left[(\mathrm{Cp} *) \mathrm{Ru}(\right.$ picolyl-NHC $\left.)\left(\mathrm{CH}_{3} \mathrm{CN}\right)\right] \mathrm{PF}_{6}{ }^{25}$

of iridium and ruthenium for $\mathrm{N}$-alkylation of amines. ${ }^{7 b}$ In addition, Peris et al. described an efficient catalytic system of iridium with $\mathrm{NHCs},\left[\mathrm{IrCl}_{2} \mathrm{Cp} *(\mathrm{NHC})\right]$, for the cross-coupling of amines and alcohols. ${ }^{26}$ However, several ruthenium and iridium catalytic systems bearing phosphine ligands have been reported to complete the $\mathrm{N}$-alkylation of amines with alcohols with good yields and selectivity. ${ }^{27}$

The permanent search for new homogeneous catalytic systems led us toward the continuation of our recent work on the synthesis of $\left[\mathrm{Cp} * \mathrm{Ru}\left(\right.\right.$ picolyl-NHC) $\left.\left(\mathrm{CH}_{3} \mathrm{CN}\right)\right]\left[\mathrm{PF}_{6}\right]$. Here we report the synthesis of a series of $[(p$-cymene $) \mathrm{Ru}($ picolyl-NHC $) \mathrm{Cl}] \mathrm{PF}_{6}$ complexes. Picolyl-NHC ligands have been varied systematically to study the influence on the catalytic activity of the wingtip substituent as well as the substituents at the C-4 and C-5 carbons of the imidazole ring. The new ruthenium compounds have shown excellent activity toward transfer hydrogenation of a wide variety of ketones and imines with high conversions. Additionally, the compounds have proved to catalyze amine $\mathrm{N}$-alkylation reactions.

\section{RESULTS AND DISCUSSION}

Synthesis of $\left(\eta^{6}-p\right.$-cymene)Ru"(picolyl-NHC) Complexes. Picolyl imidazolium salts were obtained as previously described in the literature and used as picolyl-NHC precursors. $^{25,28-31}$ At first, in situ generation of the free picolyl-NHCs by treatment of the imidazolium salts $\mathbf{a}-\mathbf{g}$ with a strong base (i.e., $\mathrm{KO}^{t} \mathrm{Bu}$ or $\mathrm{Li}^{n} \mathrm{Bu}$ ) in THF followed by the addition of the metal precursor was attempted, but the products were not obtained quantitatively; in most attempts unreacted $\left[\left(\eta^{6}-p \text {-cym }\right) \mathrm{RuCl}_{2}\right]_{2}$ was observed in the ${ }^{1} \mathrm{H}$ NMR spectrum of the reaction mixture. Hence, the transmetalation method was the route of choice to afford the new $\mathrm{Ru}$ (II) cationic complexes $1 \mathbf{a}-\mathrm{g}$ (Scheme 2). Previously, Jin et al. synthesized a half-sandwich ruthenium containing 1,2-dichalcogenolato 1,2-dicarba-closo-dodecarborane and a picolyl-NHC ligand noncoordinated by the pyridyl arm using the transmetalation path. ${ }^{32}$ Silver carbene complexes were prepared in situ upon treatment of the appropriate picolyl imidazolium salts $\mathbf{a}-\mathbf{g}$ with silver oxide in dichloromethane. The metal precursor $\left[\left(\eta^{6}-p \text {-cymene }\right) \mathrm{Ru}(\mathrm{Cl})_{2}\right]_{2}$ and an excess of $\mathrm{NaPF}_{6}$ were added to the corresponding silver carbene solution, generating the new ruthenium picolyl-NHC complexes $\mathbf{1 a}-\mathbf{g}$ in high yields (over $83 \%$ ) in all cases. The reaction is complete after $3 \mathrm{~h}$ at room temperature. The new $\mathrm{Ru}$ (II) compounds were characterized by ${ }^{1} \mathrm{H}$ and ${ }^{13} \mathrm{C}\left\{{ }^{1} \mathrm{H}\right\} \mathrm{NMR}$ and elemental analysis. All the ruthenium picolyl-NHC complexes are very soluble in THF, acetone, and chlorinated solvents but insoluble in other solvents such as hexane, diethyl ether, and petroleum ether.

${ }^{1} \mathrm{H}$ NMR spectra of compounds $\mathbf{1 a}-\mathbf{g}$ do not show the $\mathrm{NCHN}$ proton resonance signals at $10-12 \mathrm{ppm}$, as expected after the coordination of the $\mathrm{C}_{2}$ carbene carbon to the metal center. Also, ${ }^{1} \mathrm{H}$ NMR spectra show two characteristic $\mathrm{AB}$ doublet signals at 5-6 ppm with coupling constants of 15-16 $\mathrm{Hz}$ corresponding to the methylene bridge protons, which become diastereotopic after coordination of the ligands to the $\mathrm{Ru}$ atom, particularly in $\kappa^{2} \mathrm{C}, \mathrm{N}$ coordination. Furthermore, analogous NMR features for $\left(\eta^{5}-\mathrm{C}_{5} \mathrm{Me}_{5}\right) \mathrm{Ru}$ chelating $\kappa^{2} \mathrm{C}, N$ picolyl-NHC ligands and chelating $\kappa^{2} P, N$-phosphinopicoline ligands have been observed. ${ }^{25,33}$ Also, this pattern has been reported by Xue and co-workers, in the synthesis of $\mathrm{Ru}(\mathrm{II})$ carbonyl Py-NHC complexes. ${ }^{34}$ The ${ }^{13} \mathrm{C}\left\{{ }^{1} \mathrm{H}\right\}$ NMR signals of the carbene carbon atoms of $\mathbf{1 a}-\mathbf{g}(170-190 \mathrm{ppm})$ are located as expected for ( $p$-cymene) $\mathrm{Ru}(\mathrm{NHC})$ compounds. ${ }^{22 \mathrm{~d}, 32,33,35}$ It is interesting to note the displacement to lower field, up to $190 \mathrm{ppm}$, of the NMR resonance of the $\mathrm{C}_{2}$ carbon atom corresponding to the benzoimidazol analogue 1e. The lower electron density in the $\mathrm{C}_{2}$ carbon due to the destabilization of the imidazolium ring conjugation caused by the benzene ring could explain this observation. Also, this behavior was evidenced in the previous synthesis of the $\left(\eta^{5}-\mathrm{C}_{5} \mathrm{Me}_{5}\right) \mathrm{Ru}$ picolyl-NHC analogues. ${ }^{25}$

Crystals suitable for X-ray diffraction of $\mathbf{1 a , f}$ were obtained after layering the recrystallization solution on a mixture of dichloromethane and hexane (1/2). ORTEP diagrams of the two $\mathrm{Ru}(\mathrm{II})$ cationic complexes are displayed in Figures 2 and 3, along with selected interatomic distances and angles.

In these structures the ruthenium(II) metal centers adopt a pseudo-octahedral coordination geometry with all the $\mathrm{Cl}-\mathrm{Ru}-$ $\mathrm{C}_{\text {carbene, }} \mathrm{Cl}-\mathrm{Ru}-\mathrm{N}$, and $\mathrm{N}-\mathrm{Ru}-\mathrm{C}_{\text {carbene }}$ angles in the range 83.7(2) $-87.7(1)^{\circ}$.

In both cases $\eta^{6}-\pi$ - $p$-cymene and $\mathrm{Cl}$ ligands coordinate to a slightly distorted octahedral metal center that is also chelated by one NHC ligand. The interatomic distances in the coordination sphere of ruthenium are all comparable with those found in closely related chloro $p$-cymene NHC ruthenium complexes ${ }^{13 f, 35}$ or chloro $\eta^{6}$-mesitylene NHC ruthenium complexes. ${ }^{36}$ Dihedral angles between pyridyl and imidazolyl rings were found to be $55.3(3)^{\circ}$ for 1 a and $58.8(1)^{\circ}$ for 1 f.

Scheme 2

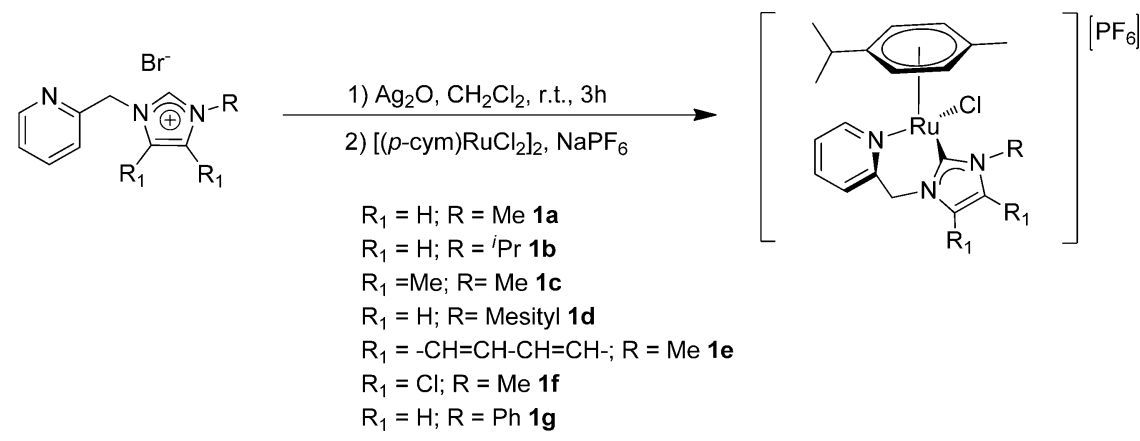




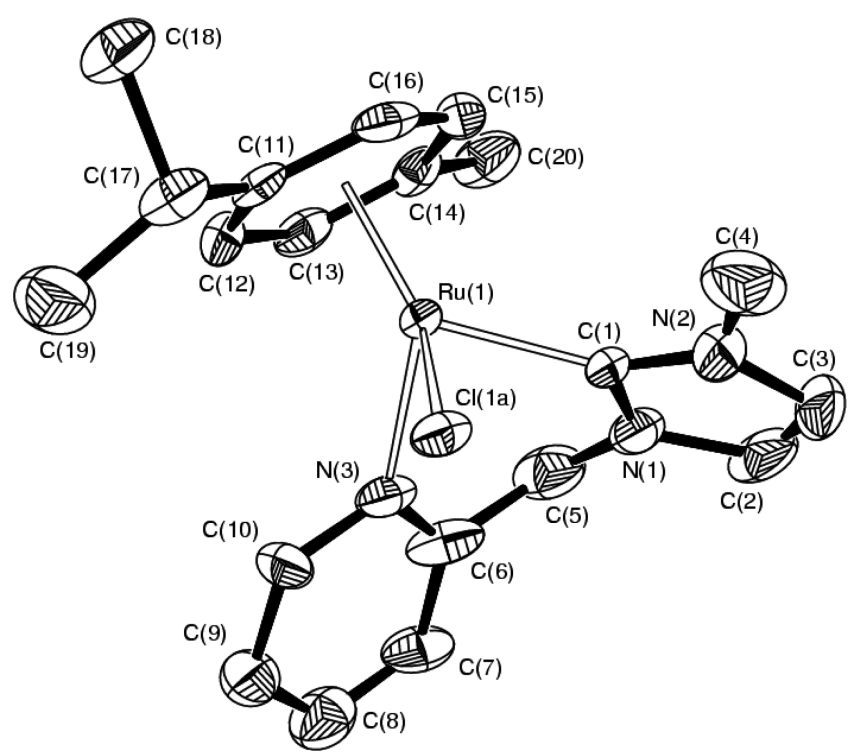

Figure 2. ORTEP diagram for the complex cation in $\left[\mathrm{RuCl}\left(\eta^{6}-p\right.\right.$ cymene) $\left.\left(\mathrm{NHC}-\kappa^{2} C, N\right)\right]\left[\mathrm{PF}_{6}\right]$ (1a; NHC = 3-methyl-1-(2-picolyl)imidazol-2-ylidene). Thermal ellipsoids are drawn at the $50 \%$ probability level. Hydrogen atoms have been omitted for clarity. Selected interatomic distances $(\AA)$ and angles (deg): $\mathrm{Ru}(1)-$ phenylidene (centroid) = 1.710(3), $\mathrm{Ru}(1)-\mathrm{Cl}(1 \mathrm{a})=2.389(2)$, $\mathrm{Ru}(1)-\mathrm{N}(3)=2.095(6), \mathrm{Ru}(1)-\mathrm{C}(1)=2.035(7) ; \mathrm{Cl}(1 \mathrm{a})-\mathrm{Ru}(1)-$ $\mathrm{N}(3)=86.32(18), \mathrm{Cl}(1 \mathrm{a})-\mathrm{Ru}(1)-\mathrm{C}(1)=84.8(3), \mathrm{N}(3)-\mathrm{Ru}(1)-$ $\mathrm{C}(1)=84.2(3)$.

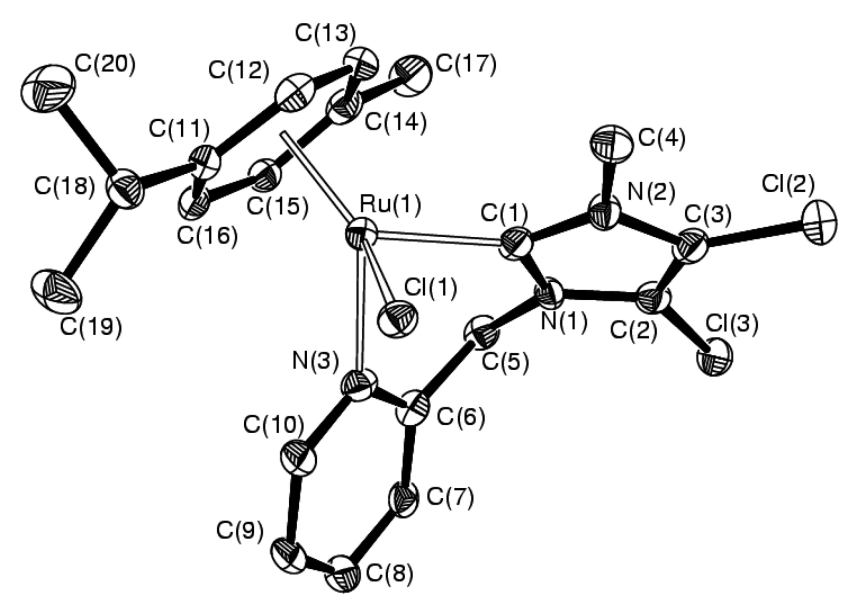

Figure 3. ORTEP diagram for the complex cation in $\left[\mathrm{RuCl}\left(\eta^{6}-p\right.\right.$ cymene) $\left.\left(\mathrm{NHC}-\kappa^{2} C, N\right)\right]\left[\mathrm{PF}_{6}\right]$ (1f; NHC = 3-methyl-1-(2-picolyl)4,5-dichloroimidazol-2-ylidene). Thermal ellipsoids are drawn at the $50 \%$ probability level. Hydrogen atoms have been omitted for clarity. Selected interatomic distances $(\AA)$ and angles (deg): $\mathrm{Ru}(1)-$ phenylidene (centroid) $=1.696(2), \mathrm{Ru}(1)-\mathrm{Cl}(1)=2.448(1)$, $\mathrm{Ru}(1)-\mathrm{N}(3)=2.111(4), \mathrm{Ru}(1)-\mathrm{C}(1)=2.023(5) ; \mathrm{Cl}(1)-\mathrm{Ru}(1)-$ $\mathrm{N}(3)=86.75(12), \mathrm{Cl}(1)-\mathrm{Ru}(1)-\mathrm{C}(1)=87.69(14), \mathrm{N}(3)-\mathrm{Ru}(1)-$ $\mathrm{C}(1)=83.70(18)$.

Catalytic N-Alkylation of Amines with Alcohols. Nitrogen-containing compounds as amines are very important due to the wide applications they have in several industrial processes and the key role they play in the synthesis of several pharmaceutically and biologically significant molecules. ${ }^{37}$ Ruthenium complexes have been commonly used as catalysts for the $\mathrm{N}$-alkylation of amines via a hydrogen autotransfer process, particularly $\mathrm{RuCl}_{2}\left(\mathrm{PPh}_{3}\right)_{3}$ and its derivatives. ${ }^{3,27}$ It is interesting that, considering the wide amount of work published on ruthenium-NHC complexes, Albretch et al. just recently described the use of ruthenium triazolylidene complexes as catalysts for oxidative coupling of alcohols and amines. ${ }^{38}$ In addition, Crabtree and co-workers have reported the use of a ruthenium pyrimidine-NHC complex as a catalyst for the $\mathrm{N}$-alkylation of amines. ${ }^{7 \mathrm{~b}}$ However, many examples with transition-metal complexes used as catalysts for this transformation have been described recently. ${ }^{36,27 a, 39,40}$ Therefore, complexes $\mathbf{1 a}-\mathbf{f}$ were tested as catalysts for this transformation.

Optimization of Reaction Conditions. The generation of $\mathrm{N}$-benzylaniline from benzyl alcohol and aniline was used as a representative reaction to optimize the reaction conditions (Scheme 3). The results given in Table 1 show the screening of

\section{Table 1. Optimization of Conditions ${ }^{a}$}

$\begin{array}{clrcc}\text { entry } & \text { base } & \text { amt of base }(\mathrm{mol} \%) & \text { yield }(\%)^{b} & \text { amine }(\%)^{c} \\ 1 & & & 0 & \\ 2 & \mathrm{NaHCO}_{3} & 15 & 0 & \\ 3 & \mathrm{NaHCO}_{3} & 50 & 0 & \\ 4 & \mathrm{NaHCO}_{3} & 100 & 0 & \\ 5 & \mathrm{KO}^{t} \mathrm{Bu} & 15 & 85 & 72 \\ 6 & \mathrm{KO}^{t} \mathrm{Bu} & 20 & 86 & 80 \\ 7 & \mathrm{KO}^{t} \mathrm{Bu} & 50 & 97 & 97 \\ 8 & \mathrm{KO}^{t} \mathrm{Bu} & 100 & >99 & >99 \\ 9 & \mathrm{~K}_{2} \mathrm{CO}_{3} & 15 & 0 & \\ 10 & \mathrm{~K}_{2} \mathrm{CO} & 50 & 0 & \\ 11 & \mathrm{~K}_{2} \mathrm{CO} & 100 & 0 & 85 \\ 12 & \mathrm{KOH} & 15 & 90 & 88 \\ 13 & \mathrm{KOH} & 20 & 88 & >99 \\ 14 & \mathrm{KOH} & 50 & >99 & >99 \\ 15 & \mathrm{KOH} & 100 & >99 & \end{array}$

${ }^{a} \mathrm{~N}$-alkylation reaction conditions: $2.00 \mathrm{mmol}$ of aniline, $2.00 \mathrm{mmol}$ of benzyl alcohol, 1a $(0.5 \mathrm{~mol} \%)$ in $2 \mathrm{~mL}$ of toluene at $100{ }^{\circ} \mathrm{C}$ for $24 \mathrm{~h}$. ${ }^{b}$ Product yield determined by GC-MS using 1,3,5-trimethoxybenzene as an internal standard. ${ }^{c}$ Conversions determined by GC-MS. The formation of the corresponding imine as a byproduct accounts for the difference in conversion.

bases as initiators of the catalytic reaction. Weak bases such as $\mathrm{NaHCO}_{3}$ and $\mathrm{K}_{2} \mathrm{CO}_{3}$ were not effective (entries 2-4 and 9-11). However, the use of strong bases such as $\mathrm{KO}^{t} \mathrm{Bu}$ and $\mathrm{KOH}$ lead to high yields of the desired product, $N$-benzylaniline (entries 5-8 and $12-15)$. In addition, to obtain almost quantitative yields and avoid the presence of the imine as a secondary product, from lack of hydrogenation of the condensation product, at least $50 \mathrm{~mol} \%$ of base is needed.

We continued the $\mathrm{N}$-alkylation reaction optimization process after finding the need for a strong base to activate the ruthenium complex 1a. The following step was to study the

Scheme 3

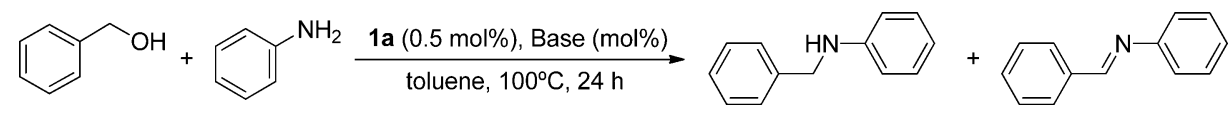


Table 2. Influence of Wingtips, Backbone Substituents, and Catalyst Loading on the Catalytic Activity of Ru(picolylcarbene) Complexes ${ }^{a}$

\begin{tabular}{ccccccc}
\hline entry & cat. & $\begin{array}{c}\text { amt of cat. } \\
(\text { mol \%) }\end{array}$ & $\begin{array}{c}\text { time } \\
(\mathrm{h})\end{array}$ & $\begin{array}{c}\text { TON }^{b} \\
(\%)^{c}\end{array}$ & $\begin{array}{c}\text { amine } \\
(\%)^{d}\end{array}$ \\
\hline 1 & 1a & 0.15 & 72 & 360 & 54 & 43 \\
2 & 1b & 0.15 & 72 & 480 & 72 & 62 \\
3 & 1c & 0.15 & 72 & 360 & 54 & 42 \\
4 & 1d & 0.15 & 72 & 373 & 56 & 46 \\
5 & 1e & 0.15 & 72 & 406 & 61 & 45 \\
6 & 1f & 0.15 & 72 & 480 & 72 & 65 \\
7 & 1a & 0.25 & 72 & 252 & 63 & 55 \\
8 & 1b & 0.25 & 72 & 296 & 74 & 64 \\
9 & 1c & 0.25 & 72 & 284 & 71 & 65 \\
10 & 1d & 0.25 & 72 & 248 & 62 & 55 \\
11 & 1e & 0.25 & 72 & 328 & 82 & 79 \\
12 & 1f & 0.25 & 72 & 288 & 72 & 61 \\
13 & 1a & 0.50 & 15 & 184 & 92 & 92 \\
14 & 1b & 0.50 & 15 & 154 & 77 & 72 \\
15 & 1c & 0.50 & 15 & 186 & 93 & 93 \\
16 & 1d & 0.50 & 15 & 164 & 82 & 78 \\
17 & 1e & 0.50 & 15 & 184 & 92 & 90 \\
18 & 1f & 0.50 & 15 & 160 & 80 & 75 \\
\hline
\end{tabular}

${ }^{a} \mathrm{~N}$-alkylation reaction conditions: $2.00 \mathrm{mmol}$ of aniline, $2.00 \mathrm{mmol}$ of benzyl alcohol, $\mathrm{KOH}(50 \mathrm{~mol} \%)$, catalyst ( $\mathrm{mol} \%)$ in $2 \mathrm{~mL}$ of toluene at $100{ }^{\circ} \mathrm{C} .{ }^{b}$ Turnover number $(\mathrm{TON})=(\mathrm{mmol}$ of product $) /(\mathrm{mmol}$ of catalyst) after time $t$. ${ }^{c}$ Product yield determined by GC-MS using 1,3,5-trimethoxybenzene as an internal standard. ${ }^{d}$ Conversions determined by GC-MS. Formation of the corresponding imine as a byproduct accounts for the difference in conversion.

influence of the wingtip, backbone substituents, and catalyst loadings on the catalytic activity. The results given in Table 2 indicate that lower catalyst loadings lead to moderate yields and longer reaction times are required to achieve maximum TONs (entries 1-12). Also, as expected, higher catalyst loadings led to higher yields and higher amine content in the product distribution (entries 1-12). Furthermore, considering the results when $0.5 \mathrm{~mol}$ $\%$ of catalyst was used, it is clear that ruthenium complexes containing Me (entries 13, 15, 17, and 18) as a wingtip substituent lead to higher yields than those containing isopropyl or mesityl (entries 2 and 4) and significantly shorter reaction times are needed to complete the $\mathrm{N}$-alkylation process. This behavior indicates that steric effects may be playing an important role in the catalytic activity. In addition, $\mathbf{1 b}$,d showed good activity at lower catalyst loadings, but when the catalyst concentration was increased, it was not possible to obtain yields as high as those with their analogues. However, it is important to note that, among complexes with methyl substituents in the wingtip, those containing methyl groups, 1c, in the imidazole backbone or a benzimidazole ring, 1e, showed the best selectivity toward the synthesis of the amine (entries 9, 11, 15, and 17). Also, to consider possible electronic effects on the catalytic activity, 1f with chloro substituents on the imidazole backbone was tested and yields and selectivity lower than those with its analogues $\mathbf{1 c}, \mathbf{e}$ were obtained under the same reaction conditions. Thus, electronic properties may also account for the catalytic activity, although not as much as steric effects.

The optimization process led us toward the determination of the best reaction conditions to analyze the substrate scope. Catalysts 1a,c,e proved to be the most efficient complexes for the $\mathrm{N}$-alkylation of aniline in terms of yield and selectivity, and
$0.5 \mathrm{~mol} \%$ catalyst loading was chosen, given the high yields and shorter reaction times needed to complete the process.

Substrate Scope. Several amines and alcohols were chosen to explore the range of application of the catalysts for the hydrogen autotransfer $\mathrm{N}$-alkylation of amines (Scheme 4). The

$$
\begin{aligned}
& \text { Scheme } 4
\end{aligned}
$$

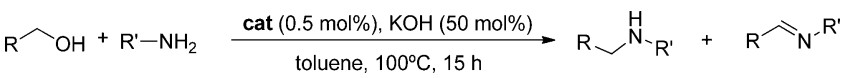

Table 3. Catalytic Aromatic Amine N-alkylation ${ }^{a}$

\begin{tabular}{|c|c|c|c|c|c|}
\hline entry & $\mathrm{R}$ & $\mathrm{R}^{\prime}$ & cat. & yield $(\%)^{b}$ & amine $(\%)^{c}$ \\
\hline 1 & $\mathrm{Ph}$ & $\mathrm{Ph}$ & $1 \mathrm{a}$ & 92 & 92 \\
\hline 2 & & & $1 c$ & 93 & 93 \\
\hline 3 & & & 1e & 92 & 92 \\
\hline 4 & $\mathrm{Ph}$ & 4-MePh & 1a & 95 & 95 \\
\hline 5 & & & $1 \mathrm{c}$ & 94 & 94 \\
\hline 6 & & & 1e & 90 & 86 \\
\hline 7 & $\mathrm{Ph}$ & 4-OMePh & $1 \mathrm{a}$ & 93 & 93 \\
\hline 8 & & & lc & 94 & 94 \\
\hline 9 & & & le & 89 & 80 \\
\hline 10 & $\mathrm{Ph}$ & 4-ClPh & $1 a$ & 92 & 92 \\
\hline 11 & & & 1c & 96 & 96 \\
\hline 12 & & & $1 \mathrm{e}$ & $>99$ & $>99$ \\
\hline 13 & $\mathrm{Ph}$ & $2-\mathrm{NH}_{2} \mathrm{Py}$ & $1 a$ & 85 & 85 \\
\hline 14 & & & $1 c$ & 75 & 75 \\
\hline 15 & 4-MePh & $\mathrm{Ph}$ & $1 a$ & 89 & 83 \\
\hline 16 & & & 1c & 93 & 91 \\
\hline 17 & & & le & 81 & 73 \\
\hline 18 & 4-OMePh & $\mathrm{Ph}$ & 1a & 92 & 92 \\
\hline 19 & & & $1 \mathrm{c}$ & 97 & 92 \\
\hline 20 & & & le & 84 & 75 \\
\hline 21 & 4-ClPh & $\mathrm{Ph}$ & $1 a$ & 94 & 94 \\
\hline 22 & & & $1 c$ & 94 & 94 \\
\hline 23 & & & $1 \mathrm{e}$ & 80 & 75 \\
\hline 24 & 1-naphthalene & $\mathrm{Ph}$ & 1a & 88 & 88 \\
\hline 25 & & & $1 \mathrm{c}$ & 86 & 86 \\
\hline 26 & & & $1 \mathrm{e}$ & 77 & 77 \\
\hline 27 & ${ }^{i} \operatorname{Pr}$ & $\mathrm{Ph}$ & $1 \mathrm{a}$ & 67 & 67 \\
\hline 28 & & & $1 \mathrm{c}$ & 69 & 69 \\
\hline 29 & & & le & 61 & 61 \\
\hline
\end{tabular}

${ }^{a} \mathrm{~N}$-alkylation reaction conditions: $2.00 \mathrm{mmol}$ of amine, $2.00 \mathrm{mmol}$ of alcohol, $\mathrm{KOH}(50 \mathrm{~mol} \%)$, catalyst $(0.5 \mathrm{~mol} \%)$ in $2 \mathrm{~mL}$ of toluene at $100{ }^{\circ} \mathrm{C}$ for $15 \mathrm{~h}$. ${ }^{b}$ Product yield determined by GC-MS and ${ }^{1} \mathrm{H}$ NMR using 1,3,5-trimethoxybenzene as an internal standard. ${ }^{c}$ Conversions determined by GC-MS. Formation of the corresponding imine as a byproduct accounts for the difference in conversion.

results shown in Table 3 summarize the effect of the substrates on the yield and selectivity of the catalytic reaction after $15 \mathrm{~h}$. The use of donor or electron-withdrawing groups in the aniline ring does not affect the catalyst performance. In all cases the corresponding amine was generated with almost quantitative yields and high selectivity (entries 1-12). However, when 2-aminopyridine was used as substrate, lower yields were obtained, indicating that when a heteroaromatic amine is used the catalytic reaction is less efficient (entries 13 and 14). In addition, in that case 1a leads to higher yields than 1c.

Alcohols are the source of the alkyl groups for the generation of the new amines. Thus, the tolerance to different substituents in benzyl alcohol derivatives toward the synthesis of amines was investigated. The use of electron-donor substituents 
(entries 15-20) indicates that the reaction yields are comparable to those when benzyl alcohol was used as substrate, but there was a small selectivity loss, evidenced by the generation of small amounts of the corresponding imine. Nonetheless, when an electron-withdrawing group such as a halogen (entries 21-23) is present, the yields and selectivity are very high. Also, the use of a bulky alcohol such as 1-naphthalene methanol (entries 24 and 25) or an alkyl alcohol such as isobutanol (entries 27-29) does not affect the selectivity of the reaction but leads to lower yields. In general, 1a,c show high tolerance to different alcohols. However, 1e showed a decrease in reaction yield in comparison with its analogues.

It is very important to note that the use of a nonaromatic amine as substrate (Table 4) generated mostly the corresponding

Table 4. Catalytic Nonaromatic Amines N-alkylation ${ }^{a}$

$\begin{array}{ccccccc}\text { entry } & \mathrm{R} & \mathrm{R}^{\prime} & \text { cat. } & \begin{array}{c}\text { amt of } \mathrm{KOH} \\ (\mathrm{mol} \%)\end{array} & \begin{array}{c}\text { yield } \\ (\%)^{b}\end{array} & \begin{array}{c}\text { imine } \\ (\%)^{c}\end{array} \\ 1 & \mathrm{Ph} & \mathrm{PhCH}_{2} & \text { 1a } & 50 & 99 & 57 \\ 2 & & & \text { 1a } & 20 & 98 & 98 \\ 3 & & & \text { 1c } & 50 & 81 & 62 \\ 4 & & & \text { 1c } & 20 & 84 & 84 \\ 5 & & & \text { 1e } & 50 & 85 & 73 \\ 6 & & & \text { 1e } & 20 & 88 & 88 \\ 7 & \mathrm{Ph} & \mathrm{Cy} & \text { 1a } & 50 & 56 & 56 \\ 8 & & & \text { 1c } & 50 & 67 & 65 \\ 9 & & & \text { 1e } & 50 & 71 & 71 \\ 10 & \mathrm{Ph} & \mathrm{PhCH}_{2} \mathrm{CH}_{2} & \text { 1e } & 50 & 75 & 69\end{array}$

${ }^{a} \mathrm{~N}$-alkylation reaction conditions: $2.00 \mathrm{mmol}$ of amine, $2.00 \mathrm{mmol}$ of alcohol, $\mathrm{KOH}(\mathrm{mol} \%)$, catalyst $(0.5 \mathrm{~mol} \%)$ in $2 \mathrm{~mL}$ of toluene at $100{ }^{\circ} \mathrm{C}$ for $24 \mathrm{~h}$. ${ }^{b}$ Product yield determined by GC-MS and ${ }^{1} \mathrm{H}$ NMR using 1,3,5-trimethoxybenzene as an internal standard. ${ }^{c}$ Conversions determined by GC-MS. Formation of the corresponding amine as a byproduct accounts for the difference in conversion.

imine as the reaction product. The use of lower amounts of base (entries 2, 4, and 6) led to higher selectivity toward the imine when benzylamine was used as substrate. Also, several experiments were conducted by increasing the base loading up to $200 \mathrm{~mol} \%$, catalyst loading up to $5 \%$, and reaction temperatures up to $150{ }^{\circ} \mathrm{C}$ and in no case an evident improvement toward the amine synthesis was observed. These results indicate that the late stage of the hydrogen autotransfer mechanism is disrupted.

Usually, imines are obtained during the preparation of amines, but as a side product in small yields or as species detected as reaction intermediates. Just a few examples of catalysts used for selective imine synthesis are known. ${ }^{27,39}$ Particularly, Milstein and co-workers reported selective imine synthesis of imines with a ruthenium PNP pincer complex. ${ }^{27 a}$ However, this is the first example of selective imine synthesis using ruthenium NHC complexes as catalysts. Catalysts $\mathbf{1 a}, \mathbf{c}, \mathbf{e}$ performed better than previously reported catalytic systems, ${ }^{39}$ although the most efficient catalysts reported to date for the selective synthesis of imines is Milstein's ruthenium PNP pincer complex. ${ }^{27 a}$ In addition, 1a,c,e to the best of our knowledge are the most effective ruthenium catalysts reported for the N-alkylation of aromatic amines, given the high yields and low catalyst loadings needed to complete the transformation in comparison to other ruthenium systems. ${ }^{3 \mathrm{~b}, 27 \mathrm{~d}-\mathrm{f}, 41}$

Mechanistic Study. To gain further understanding of the $\mathrm{N}$-alkylation process, considering it follows the "borrowing hydrogen" pathway, we conducted two experiments using
Table 5. Dehydrogenation of Aromatic Alcohols ${ }^{a}$

$\begin{array}{clcc}\text { entry } & \text { substrate } & \text { time }(\mathrm{h}) & \text { yield }^{b}(\%) \\ 1 & \text { benzyl alcohol } & 24 & <2 \\ 2 & \text { 1-phenylethanol } & 24 & 38\end{array}$

${ }^{a}$ Dehydrogenation reaction conditions: $2.00 \mathrm{mmol}$ of alcohol, $\mathrm{KOH}$ ( $50 \mathrm{~mol} \%)$, catalyst $(2 \mathrm{~mol} \%)$ in $2 \mathrm{~mL}$ of toluene at $100{ }^{\circ} \mathrm{C}$. ${ }^{b}$ Product yield determined by GC-MS and ${ }^{1} \mathrm{H}$ NMR using 1,3,5-trimethoxybenzene as an internal standard.

\section{Scheme 5}

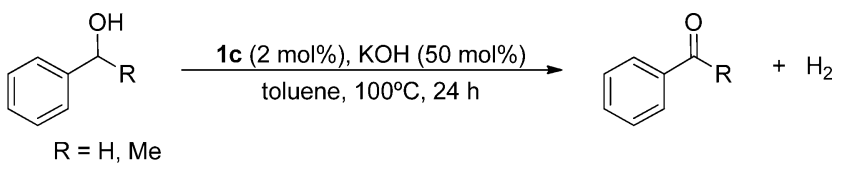

benzyl alcohol and 1-phenylethanol as substrates (Table 5). The aim was to assess if the corresponding oxidation reaction was completed (Scheme 5). ${ }^{7 b, 26,38}$ No aldehyde was observed in the reaction mixture after $24 \mathrm{~h}$ when benzyl alcohol was used as a substrate. Thus, the aldehyde should be a short-lived intermediate or it does not dissociate from the metal center before being condensed with the corresponding amine in the $\mathrm{N}$-alkylation reaction. However, in the case of 1-phenylethanol, acetophenone was observed as a product. No further experiments for optimization of the oxidation reaction were completed. Nonetheless, this result indicates that catalysts $\mathbf{1 a}-\mathbf{f}$ may be used in a wider range of reactions. We will further investigate the $\beta$-alkylation of alcohols and secondary alcohol oxidation reactions.

Also, to gain more insight into the reaction mechanism and intermediates, we conducted NMR reactions in toluene- $d_{8}$ with higher catalyst loadings (6 mol \% of 1c) to be able to detect intermediates, using aniline and benzyl alcohol as substrates, and $50 \% \mathrm{KO}^{t} \mathrm{Bu}$. Immediately, after the addition of substrates and base the ${ }^{1} \mathrm{H}$ NMR spectrum recorded at room temperature showed the formation of two ruthenium hydride species, as evidenced by the appearance of two singlets, at $-8.2 \mathrm{ppm}$ (minor) and $-9.4 \mathrm{ppm}$ (major). This indicates a quick exchange of the chloride with the alkoxide, as an initiation step that does not require heating. The reaction mixture was heated at $100{ }^{\circ} \mathrm{C}$ for $15 \mathrm{~h}$ in an oil bath, and while the formation of $\mathrm{N}$-benzylamine progressed, the initial hydride peaks disappeared and many weak peaks appeared in the ${ }^{1} \mathrm{H}$ NMR spectrum between -11 and $-25 \mathrm{ppm}$. Furthermore, to confirm the initial formation of the ruthenium hydride alkoxide specie as the initial step, an NMR experiment on toluene- $d_{8}$ with a 1:4:4 ratio of $1 \mathrm{c}, \mathrm{KO}^{t} \mathrm{Bu}$, and benzyl alcohol was conducted. At first, at room temperature two hydride peaks at -9.4 and -8.6 ppm were observed, which disappeared after prolonged heating of the sample at $100{ }^{\circ} \mathrm{C}$. The catalyst decomposition was confirmed by the disappearance of the characteristic $\pi$-bound $p$-cymene protons and the doublets corresponding to the $\kappa^{2} C, N$ picolylimidazolidene close to 4-6 ppm. The hydride peak at $-9.4 \mathrm{ppm}$ in the ${ }^{1} \mathrm{H}$ NMR spectrum confirms the formation of species similar to that formed in the previous $\mathrm{N}$-alkylation experiment. Finally, to complete our study, when the experiment was ran without the presence of a base, with only a $1 / 4$ ratio of $1 \mathrm{c}$ and benzyl alcohol, no hydride peaks were observed in the ${ }^{1} \mathrm{H}$ NMR spectrum.

In addition, to obtain further information concerning the reaction mechanism, the reaction of aniline with an equimolar amount of benzaldehyde and a catalytic amount of benzyl 
Scheme 6

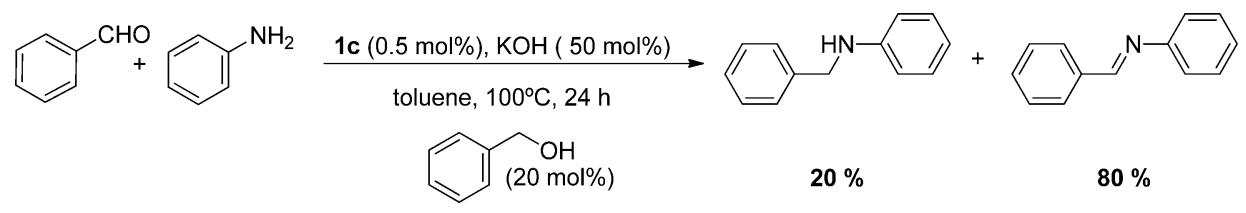

alcohol, 1c, and $\mathrm{KOH}$ was conducted (Scheme 6). The reaction was completed after heating the mixture for $24 \mathrm{~h}$ at $100{ }^{\circ} \mathrm{C}$. However, the product distribution was 20/80 amine/imine. The presence of amine in the reaction mixture indicates that part of the generated imine has been hydrogenated, in contrast to results reported by Madsen and co-workers. ${ }^{42}$ Also, the completion of the reaction with benzaldehyde confirms that the reaction proceeds through an aldehyde intermediate. The presence of the imine implies the formation of an hemiaminal intermediate that is released from the catalyst, and the consequent water loss leads to the imine. In addition, a non free hemiaminal intermediate would have produced an amide, as has been reported for several ruthenium(II) catalysts. ${ }^{43}$

On the basis of the above results and the known chemistry of $\mathrm{N}$-alkylation, ${ }^{7,3 \mathrm{a}}$ transfer hydrogenation, ${ }^{8,44 a, c}$ and amide synthesis $3,35 c, 43,44 \mathrm{~b}$ reactions with ruthenium complexes, we propose the mechanism illustrated in Scheme 7. The initial step

Scheme 7. Proposed Mechanism

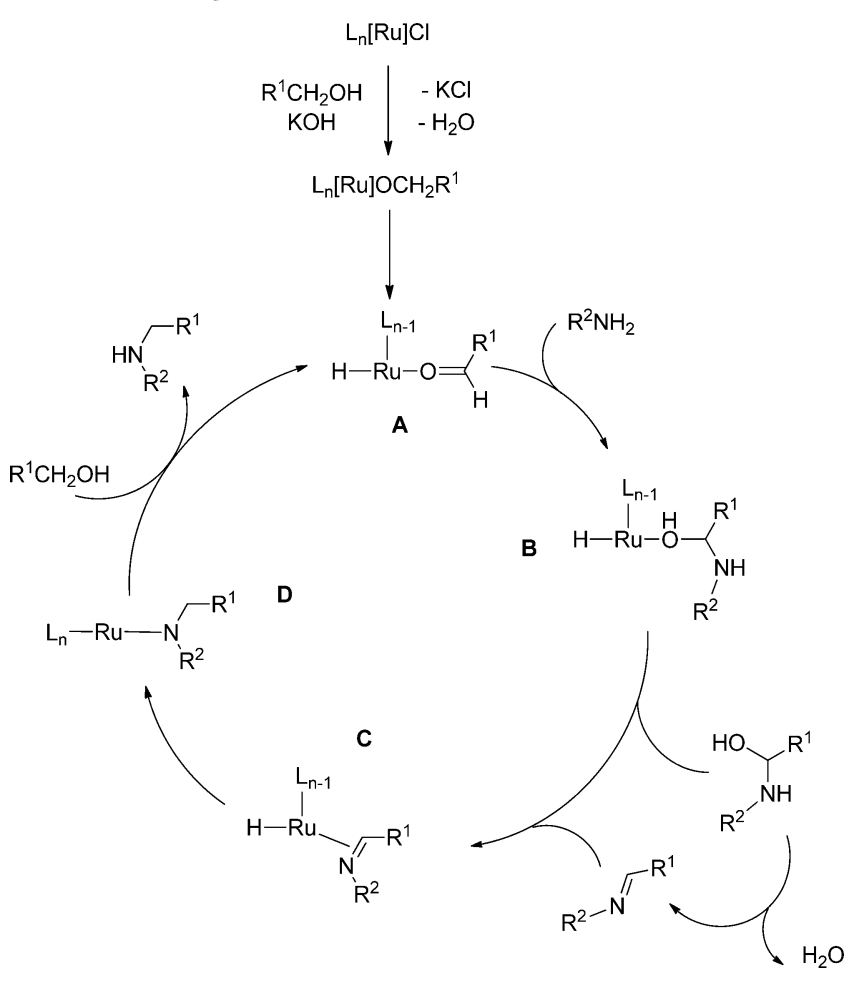

is alkoxide formation and subsequent oxidation to the aldehyde with the generation of a ruthenium hydride intermediate (A). Given that no free aldehyde is observed in the reaction mixture, we suggest the formation of a hemiaminal by condensation of the aldehyde and the amine (B) while the aldehyde is coordinated to the metal center. The following step is the hemiaminal release and water elimination, leading to the imine. This pathway diverges from other reported ruthenium systems, where the hemiaminal is coordinated to the metal and undergoes $\beta$-hydrogen loss, generating the amide. ${ }^{35,42-44}$ However, in our case, amide has not been observed as a product in any reaction. The proposed mechanism indicates that the imine is subsequently hydrogenated by hydrogen transfer to generate the secondary amine $(\mathbf{C}-\mathbf{D})$. Nonetheless, this mechanism does not explain the disruption of the late hydrogenation step to generate secondary amines when nonaromatic amines are used as substrates. Further experiments are ongoing to explain these results.

Our catalyst system has proven to be very effective toward a wide range of amines and alcohols for the synthesis of amines with high yields and selectivity when aromatic amines are used as substrates. Also, 1a,c,e have proven to be an alternative for the selective synthesis of imines, which are key intermediates for the manufacture of commercially important compounds such as agrochemicals, dyes, and medicines. ${ }^{39}$ Furthermore, $\mathbf{l a}, \mathbf{c}, \mathbf{e}$ proved to be an alternative to widely used ruthenium phosphine complexes in the advance toward the generation of more environmentally friendly processes.

Catalytic Transfer Hydrogenation. Some rutheniumNHC complexes have been reported as catalysts for the transfer hydrogenation of ketones, ${ }^{8 b, 45,46}$ including our recently reported pentamethylcyclopentadienyl $\mathrm{Ru}$-(picolylcarbene) analogues. ${ }^{25}$ Thus, ruthenium-(picolylcarbene) complexes $\mathbf{1 a}-\mathbf{f}$ were tested as catalysts for this transformation. The ruthenium(picolylcarbene) complexes catalyze the transfer hydrogenation of ketones and imines from ${ }^{i} \mathrm{PrOH}$ with $\mathrm{KOH}$ as the initiator (Scheme 8).

\section{Scheme 8}

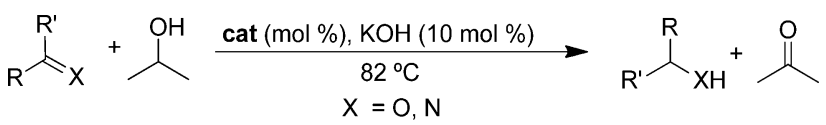

The generation of 1-phenylethanol from acetophenone was used as a representative reaction to screen the performance of $\mathrm{Ru}$-(picolylcarbene) catalysts. The results given in Table 6

Table 6. Influence of Wingtips and Backbone Substituents on the Catalytic Activity of $\mathrm{Ru}$ (picolyl-carbene) Complexes ${ }^{a}$

\begin{tabular}{|c|c|c|c|c|c|c|}
\hline entry & cat. & $\begin{array}{l}\text { cat. } \mathrm{R} \\
\text { wingtip } \\
\text { group }\end{array}$ & $\begin{array}{l}\text { cat. } \mathrm{R}_{1} \\
\text { backbone } \\
\text { group }\end{array}$ & $t(\mathrm{~h})$ & $\mathrm{TON}^{b}$ & $\begin{array}{l}\text { yield } \\
(\%)^{c}\end{array}$ \\
\hline 1 & 1a & $\mathrm{Me}$ & $\mathrm{H}$ & 2 & 184 & 92 \\
\hline 2 & $1 b$ & ${ }^{i} \mathrm{Pr}$ & $\mathrm{H}$ & 2 & 174 & 87 \\
\hline 3 & $1 c$ & $\mathrm{Me}$ & $\mathrm{Me}$ & 2 & 166 & 83 \\
\hline 4 & $1 d$ & mesityl & $\mathrm{H}$ & $2(4)$ & 34 (148) & $17(74)$ \\
\hline 5 & $1 \mathrm{e}$ & $\mathrm{Me}$ & $\begin{array}{l}-\mathrm{CH}= \\
\mathrm{CHCH}= \\
\mathrm{CH}-\end{array}$ & 2 & 178 & 89 \\
\hline 6 & If & $\mathrm{Me}$ & $\mathrm{Cl}$ & 2 & 180 & 90 \\
\hline
\end{tabular}

${ }^{a}$ Transfer hydrogenation reaction conditions: $2.00 \mathrm{mmol}$ of acetophenone, $\mathrm{KOH}(10 \mathrm{~mol} \%)$, catalyst $(0.5 \mathrm{~mol} \%)$ in $4 \mathrm{~mL}$ of ${ }^{i} \mathrm{PrOH}$ at $82{ }^{\circ} \mathrm{C} .{ }^{b}$ Turnover number $(\mathrm{TON})=(\mathrm{mmol}$ of product $) /$ (mmol of catalyst) after time $t .{ }^{c}$ Product yield determined by GC-MS using 1,3,5-trimethoxybenzene as an internal standard. 
Table 7. Catalytic Transfer Hydrogenation

\begin{tabular}{|c|c|c|c|c|c|c|}
\hline Entry & Substrate & Product & Catalyst & $t$ (h) & TON $^{b}$ & Yield $(\%)^{c}$ \\
\hline 1 & & & $1 \mathrm{a}$ & 15 & 445 & 89 \\
\hline 2 & & & 1f & 15 & 460 & 92 \\
\hline 3 & & & $1 \mathbf{a}$ & 15 & 460 & 92 \\
\hline 4 & & & 1f & 15 & 430 & 86 \\
\hline 5 & & & $1 \mathbf{a}$ & 15 & 495 & $>99$ \\
\hline 6 & & & 1f & 15 & 445 & 89 \\
\hline 7 & & & $1 \mathbf{a}$ & 15 & 490 & 98 \\
\hline 8 & & & 1f & 15 & 465 & 93 \\
\hline 9 & & & $1 \mathbf{a}$ & 24 & 385 & 77 \\
\hline 10 & & & 1f & 24 & 320 & 64 \\
\hline 11 & & & $1 \mathbf{a}$ & 15 & 470 & 94 \\
\hline 12 & & & 1f & 15 & 400 & 80 \\
\hline 13 & & & $1 \mathbf{a}$ & 6 & 490 & 97 \\
\hline 14 & & & 1f & 8 & 440 & 88 \\
\hline 15 & & & $1 \mathbf{a}$ & 6 & 495 & $>99$ \\
\hline 16 & & & 1f & 6 & 495 & $>99$ \\
\hline 17 & & $\mathrm{OH}$ & $1 \mathbf{a}$ & 6 & 495 & $>99$ \\
\hline 18 & & & 1f & 6 & 495 & $>99$ \\
\hline 19 & & & 1a & 6 & 465 & 93 \\
\hline 20 & & & 1f & 8 & 375 & 75 \\
\hline 21 & & & $1 \mathbf{a}$ & 15 & 495 & $>99$ \\
\hline 22 & & & 1f & 15 & 495 & $>99$ \\
\hline
\end{tabular}

${ }^{a}$ Transfer hydrogenation reaction conditions: $2.00 \mathrm{mmol}$ of substrate, $\mathrm{KOH}(10 \mathrm{~mol} \%)$, catalyst $(0.2 \mathrm{~mol} \%)$ in $4 \mathrm{~mL}$ of ${ }^{i} \mathrm{PrOH}$ at $82{ }^{\circ} \mathrm{C} .{ }^{b} \mathrm{Turnover}$ number $(\mathrm{TON})=(\mathrm{mmol}$ of product $) /(\mathrm{mmol}$ of catalyst $)$ after time $t .{ }^{c}$ Product yield determined by GC-MS using $1,3,5$-trimethoxybenzene as an internal standard.

show the influence of the wingtip and imidazole backbone substituents on the catalytic activity. Catalysts containing a bulky mesityl (1d) or isopropyl group (1b) (entries 2 and 4) as a wingtip substituent are less active than those containing methyl groups (entries 1, 5, and 6). Also, when electron-donor methyl substituents were introduced in the imidazole backbone (entry 3 ), lower yields were obtained in comparison with the electronwithdrawing analogue containing chloro substituents in the imidazole backbone (entry 6). However, it is important to note that steric effects may play a greater role in the catalytic activity than electronic effects, as evidenced by the lower yields obtained when bulkier groups were used as wingtip substituents. This behavior is in line with our previously synthesized pentamethylcyclopentadienyl ruthenium(picolyl-carbene) analogues. ${ }^{25}$
Catalysts 1a,f proved to be very efficient complexes in the transfer hydrogenation of acetophenone. Hence, several aromatic and aliphatic ketones as well as imines were chosen to explore the activity of $\mathbf{1 a , f}$ toward transfer hydrogenations (Table 7). Aromatic halo substituents in para positions have an enhancing effect on the catalytic activity, showing almost quantitative results on the formation of the corresponding alcohols (entries 1-8). On the other hand, the presence of a methoxy group at the para position led to lower reaction yields for acetophenones (entries 9 and 10), indicating a less efficient hydrogenation process. However, when three methoxy groups were introduced in the aromatic ring, the yields obtained were higher (entries 11 and 12), indicating that the initial deactivating effect of a single methoxy group was overcome 
by the presence of two additional donor groups. Thus, electronwithdrawing groups at the para position of acetophenones benefit the catalytic activity, while electron donating groups decrease it, unless more than one donating group is present in the aromatic ring. Also, bulkier aromatic ketones were tested. Among them, benzophenone generated 1,1-diphenylmethanol in high yields (entries 13 and 14). Also, when the more rigid ketone 9-fluorenone was used, the yields were almost quantitative (entries 15 and 16).

Complexes 1a,f were shown to be very active toward alkyl ketones. Particularly, cyclohexanone was reduced to cyclohexanol almost quantitatively (entries 17 and 18). Unsaturated ketones are interesting substrates for transfer hydrogenation reactions, because they may undergo reduction on the carbonyl and/or olefin moiety. However, 1a,f proved to selectively reduce the carbonyl moiety on 6-methylhept-5-en-2-one (entries 19 and 20). Moreover, complexes 1a,f work as efficient catalysts in the hydrogenation of $\mathrm{N}$-benzylideneaniline (entries 21 and 22), demonstrating the versatility of the new catalyst toward the hydrogenation of ketones and imines. In addition, it is clear that on comparison of the performances of $\mathbf{1 a}$ and $\mathbf{1 f}, \mathbf{1 a}$ is a better catalyst for this transformation, as evidenced by the higher yields obtained in comparison to its analogue in the cases where the reactions were not completed quantitatively. In addition, higher catalyst loadings up to $0.75 \mathrm{~mol} \%$ allowed significant shortening of reaction times (see the Supporting Information for details). In comparison with previously reported ruthenium(II) complexes bearing chelating NHCs, our catalytic system led to better yields and lower catalyst loadings were needed to complete the hydrogenation of a wide range of ketones and imines. ${ }^{45 \mathrm{~b}-\mathrm{e}, \mathrm{g}-\mathrm{i}}$ However, during the preparation of this work, Ohara and co-workers reported the synthesis of ruthenium(II) complexes bearing primary aminoNHC ligands and their activity as catalysts in the transfer hydrogenation of ketones, showing that using lower catalyst loadings up to $0.08 \mathrm{~mol} \%$ can lead to moderate to good yields on many cases, but their catalyst lack of selectivity when $\alpha, \beta$ unsaturated ketones were used as substrates. ${ }^{45}$

Transition-metal-catalyzed hydrogen transfer reactions usually follow a "hydride" mechanism which may proceed via either a monohydride or dihydride intermediate species in the catalytic cycle. Labeling protocols reported by Pàmes and Bäckvall $^{47}$ and by Crabtree et al. ${ }^{20 e}$ allowed us to distinguish between the two possible catalytic pathways. The main characteristic of the monohydride route is that the $\mathrm{C}-\mathrm{H}$ bond from the hydrogen donor ends up as a $\mathrm{C}-\mathrm{H}$ bond on the carbinol carbon of the product. On the other hand, when the dihydride route is observed, the $\mathrm{C}-\mathrm{H}$ from the donor is scrambled between the $\mathrm{C}-\mathrm{H}$ and $\mathrm{O}-\mathrm{H}$ in the product. Hence, when a hydrogen donor deuterated in the carbinol carbon is used, and the reaction proceeds via a monohydride pathway, deuterium incorporation will be only observed in the carbinol carbon of the product. However, if the reaction follows the dihydride mechanism, deuterium is observed in the carbinol carbon and oxygen. Commercially available 2-propanol-2- $d$ was used to study the transfer hydrogenation of benzophenone using 1a as catalyst (Scheme 9).

After $2 \mathrm{~h}$ of reaction time NMR and GC-MS analysis showed that mostly monodeuterated 1,1-diphenylmethanol-1-d was observed as a product with $84 \%$ of deuterium incorporation in the carbinol position. Furthermore, longer reaction times did not increase the reaction yields or the deuterium incorporation rates. This results are in line with a monohydride mechanism,
Scheme 9

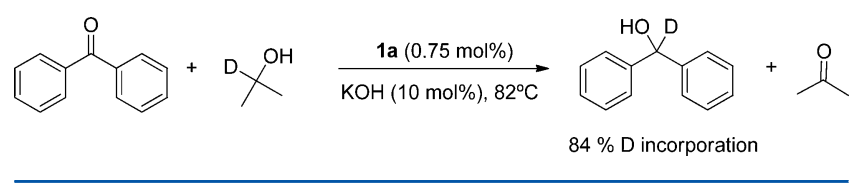

as has also been reported for other ruthenium arene complexes such as $[(p$-cymeme $) \mathrm{Ru}(\mathrm{dppp}) \mathrm{Cl}] \mathrm{Cl}(\mathrm{dppp}=1,3$-bis(diphenylphosphino)propane $)$ and $[(p$-cymene $) \mathrm{Ru}($ bipy $) \mathrm{Cl}]$ $\mathrm{Cl}$ analogues (bipy = bipyridine) ${ }^{48}$

\section{CONCLUSION}

We have reported the synthesis and characterization of the novel air-stable complexes $[(p$-cymene $) \mathrm{Ru}($ picolyl-NHC $)$ $(\mathrm{Cl})]\left[\mathrm{PF}_{6}\right](\mathbf{l a}-\mathbf{g})$, in which the substituents on the NHC backbone and wingtip have been modified. The crystal structures of two of the complexes prepared, $\mathbf{1 a}, \mathbf{f}$, have been described. The catalytic study of $[(p$-cymene $) \mathrm{Ru}($ picolyl$\mathrm{NHC})(\mathrm{Cl})]\left[\mathrm{PF}_{6}\right]$ complexes $\mathbf{1 a}-\mathbf{f}$ toward amine $\mathrm{N}$-alkylation and transfer hydrogenation reactions was completed, showing that all catalysts are active toward catalytic transformations. The results also showed that steric effects in the ligands play a more important role than electronic effects in the catalytic activity of the new complexes.

In the $\mathrm{N}$-alkylation process complexes $\mathbf{1 a , c}, \mathbf{e}$ have been proven to be versatile and efficient catalysts under mild conditions in comparison to its analogues and other ruthenium and iridium complexes. $^{3,39}$ Also, 1a,c have shown high tolerance to functional groups in the amine and alcohol moieties. Furthermore, 1a,c,e have been proven to selectively catalyze the synthesis of imines when nonaromatic amines are used as substrates. Several experiments allowed the detection of reaction intermediates and the proposal of a reaction mechanism which implies the imine generation after water elimination from the hemiaminal, as key steps to generate secondary amines.

On the other hand, 1a,f have been proven to be very efficient and versatile in transfer hydrogenation reactions of a wide variety of ketones and imines. Moreover, a monohydride transfer hydrogenation mechanism is proposed after deuterium labeling experiments.

\section{EXPERIMENTAL SECTION}

General Methods. Unless otherwise stated, all manipulations were carried out under dry nitrogen or argon using conventional Schlenk techniques. Dichloromethane, hexane, toluene, and isopropyl alcohol were of anhydrous quality and were used as received. All solvents were degassed immediately prior to use. 3-methyl-1-(2-picolyl)imidazolium bromide $(\mathbf{a}){ }^{28} 3$-isopropyl-1-(2-picolyl)imidazolium bromide $(\mathbf{b}),{ }^{29} 3$ mesityl-1-(2-picolyl)imidazolium bromide (d), ${ }^{30}$ 3-methyl-1-(2-picolyl)benzoimidazolium bromide (e), ${ }^{31}$ 3-phenyl-1-(2-picolyl)imidazolium bromide, ${ }^{25}$ 3-methyl-1-(2-picolyl)-4,5-dichloroimidazolium bromide, ${ }^{25}$ 3,4,5-trimethyl-1-(2-picolyl)imidazolium bromide, ${ }^{25}$ [( $p$-cymene $)$ $\left.\mathrm{RuCl}_{2}\right]_{2}{ }^{49}$ and $\mathrm{NaBAr}_{4}^{\mathrm{F}}{ }_{4}$, were prepared using slightly modified versions of the published procedures. All other reagents were purchased from commercial sources and used without further purification.

NMR spectra were recorded using a Varian INOVA $400 \mathrm{MHz}$ spectrometer, and chemical shifts are reported relative to TMS for ${ }^{1} \mathrm{H}$ and ${ }^{13} \mathrm{C}\left\{{ }^{1} \mathrm{H}\right\}$. Assignments of ${ }^{1} \mathrm{H}$ and ${ }^{13} \mathrm{C}\left\{{ }^{1} \mathrm{H}\right\}$ NMR spectra were made on the basis of $2 \mathrm{D}$ NMR experiments. Microanalyses were performed with a LECO CHNS-932 elemental analyzer by Servicios Centrales de Ciencia y Tecnología, Universidad de Cádiz. GC-MS analyses were recorded in an Agilent 6890N device equipped with an HP-5 column. 
Representative Procedure for Synthesis of Metal Complexes. A suspension of the appropriate imidazolium bromide $(\mathbf{a}-\mathbf{g})$ and silver oxide ( 0.5 equiv) was stirred at room temperature in the dark for $3 \mathrm{~h}$. The mixture was then filtered through a pad of Celite into $[(p-$ cymene) $\left.\left.\mathrm{RuCl}_{2}\right)\right]_{2}$ and $\mathrm{NaPF}_{6}$ (2.1 equiv) and stirred at room temperature for $3 \mathrm{~h}$. The suspension was filtered through Celite to remove silver salts, and the solvent was removed under reduced pressure. The resulting solid was washed with ether, dried under vacuum, and recrystallized from $\mathrm{CH}_{2} \mathrm{Cl}_{2} /$ hexane.

Chloro $\left(\eta^{6}\right.$-p-cymene) $\left(\kappa^{2} C, N\right.$-3-methyl-1-(2-picolyl)imidazol2-ylidene)ruthenium(II) Hexafluorophosphate (1a). Transmetalation was carried out in $\mathrm{CH}_{2} \mathrm{Cl}_{2}(30 \mathrm{~mL})$ with 3-methyl-1-(2picolyl)imidazolium bromide (a; $254.1 \mathrm{mg}, 1 \mathrm{mmol}), \mathrm{Ag}_{2} \mathrm{O}$ (115.9 mg, $0.5 \mathrm{mmol}),\left[(p\right.$-cymene $\left.\left.) \mathrm{RuCl}_{2}\right)\right]_{x}(306.2 \mathrm{mg}, 1 \mathrm{mmol})$, and $\mathrm{NaPF}_{6}$ $(352.7 \mathrm{mg}, 2.1 \mathrm{mmol})$. The product was a yellow microcrystalline solid. Yield: $506.47 \mathrm{mg}, 86 \% .{ }^{1} \mathrm{H}$ NMR $\left(\mathrm{CDCl}_{3}, 400 \mathrm{MHz}, \mathrm{SiMe}_{4}\right): \delta$ $9.14\left(\mathrm{~d},{ }^{3} J_{\mathrm{HH}}=5.86 \mathrm{~Hz}, 1 \mathrm{H}, \mathrm{H}_{\text {pyridine }}\right), 7.77\left(\mathrm{t}, 1 \mathrm{H},{ }^{3} J_{\mathrm{HH}}=8.11 \mathrm{~Hz}, 1 \mathrm{H}\right.$, $\mathrm{H}_{\text {pyridine }}$ ), $7.68\left(\mathrm{~d},{ }^{3} \mathrm{~J}_{\mathrm{HH}}=7.03 \mathrm{~Hz}, 1 \mathrm{H}, \mathrm{H}_{\text {pyridine }}\right), 7.45\left(\mathrm{~d},{ }^{3} J_{\mathrm{HH}}=1.75\right.$ $\left.\mathrm{Hz}, 1 \mathrm{H}, \mathrm{H}_{\text {imid }}\right), 7.29\left(\mathrm{t},{ }^{3} J_{\mathrm{HH}}=7.32 \mathrm{~Hz}, 1 \mathrm{H}, \mathrm{H}_{\text {pyridine }}\right), 7.03\left(\mathrm{~d},{ }^{3} \mathrm{~J}_{\mathrm{HH}}=\right.$ $\left.1.46 \mathrm{~Hz}, 1 \mathrm{H}, \mathrm{H}_{\text {imid }}\right), 5.66\left(\mathrm{~d},{ }^{3} J_{\mathrm{HH}}=6.15 \mathrm{~Hz}, 1 \mathrm{H}, \mathrm{H}_{\text {arom }}\right), 5.63\left(\mathrm{~d},{ }^{2} J_{\mathrm{HH}}\right.$ $\left.=15.94 \mathrm{~Hz}, 1 \mathrm{H}, \mathrm{H}_{\text {bridge }}\right), 5.62\left(\mathrm{~d},{ }^{3} J_{\mathrm{HH}}=6.15 \mathrm{~Hz}, 1 \mathrm{H}, \mathrm{H}_{\text {arom }}\right), 5.58(\mathrm{~d}$, $\left.{ }^{3} J_{\mathrm{HH}}=6.16 \mathrm{~Hz}, 1 \mathrm{H}, \mathrm{H}_{\text {arom }}\right), 5.51\left(\mathrm{~d},{ }^{3} J_{\mathrm{HH}}=5.86 \mathrm{~Hz}, 1 \mathrm{H}, \mathrm{H}_{\text {arom }}\right), 5.08$ $\left(\mathrm{d},{ }^{2} J_{\mathrm{HH}}=14.82 \mathrm{~Hz}, 1 \mathrm{H}, \mathrm{H}_{\text {bridge }}\right), 3.91\left(\mathrm{~s}, 3 \mathrm{H}, \mathrm{NCH}_{3}\right), 2.76\left(\mathrm{~m},{ }^{3} J_{\mathrm{HH}}=\right.$ 6.88, $\left.1 \mathrm{H}, \mathrm{CH}\left(\mathrm{CH}_{3}\right)_{2}\right), 2.12\left(\mathrm{~s}, 3 \mathrm{H}, \mathrm{CH}_{3}\right), 1.19\left(\mathrm{~d},{ }^{3} \mathrm{~J}_{\mathrm{HH}}=7.03 \mathrm{~Hz}, 3 \mathrm{H}\right.$, $\left.\mathrm{CHCH}_{3}\right), 1.15\left(\mathrm{~d},{ }^{3} \mathrm{H}_{\mathrm{HH}}=7.03 \mathrm{~Hz}, 3 \mathrm{H}, \mathrm{CHCH}_{3}\right) .{ }^{13} \mathrm{C}\left\{{ }^{1} \mathrm{H}\right\} \mathrm{NMR}$ $\left(\mathrm{CDCl}_{3}, 100 \mathrm{MHz}, \mathrm{SiMe}_{4}\right): \delta 173.29\left(\mathrm{C}_{\text {imid }} \mathrm{Ru}\right), 157.52\left(\mathrm{C}_{\text {pyridine }}\right)$, 156.60 ( $\left.\mathrm{C}_{\text {pyridine }}\right), 139.41$ ( $\left.\mathrm{C}_{\text {pyridine }}\right), 125.78$ ( $\left.\mathrm{C}_{\text {pyridine }}\right), 124.47$ $\left(\mathrm{C}_{\text {pyridine }}\right), 123.62\left(\mathrm{C}_{\text {imid }}\right), 123.12\left(\mathrm{C}_{\text {imid }}\right), 111.91\left(\mathrm{C}_{\text {arom }}\right), 101.79$ $\left(\mathrm{C}_{\text {arom }}\right), 87.83\left(\mathrm{C}_{\text {arom }}\right), 85.68\left(\mathrm{C}_{\text {arom }}\right), 85.31\left(\mathrm{C}_{\text {arom }}\right), 84.86\left(\mathrm{C}_{\text {arom }}\right)$, $54.79\left(\mathrm{CH}_{2}\right), 37.75\left(\mathrm{NCH}_{3}\right), 31.26(\mathrm{CH}), 23.30\left(\mathrm{CHCH}_{3}\right), 21.47$ $\left(\mathrm{CHCH}_{3}\right), 19.91\left(\mathrm{CH}_{3}\right)$. Anal. Calcd for $\mathrm{C}_{20} \mathrm{H}_{25} \mathrm{ClF}_{6} \mathrm{~N}_{3} \mathrm{PRu}$ : C, 40.79; H, 4.28; N, 7.14. Found: C, 40.54; H, 4.17; N, 7.17.

Chloro ( $\eta^{6}$-p-cymene) $\left(\kappa^{2} C, N\right.$-3-isopropyl-1-(2-picolyl)imidazol-2-ylidene)ruthenium(II) Hexafluorophosphate (1b). Transmetalation was carried out in $\mathrm{CH}_{2} \mathrm{Cl}_{2}(30 \mathrm{~mL})$ with 3isopropyl-1-(2-picolyl)imidazolium bromide (b; $283.2 \mathrm{mg}, 1 \mathrm{mmol})$, $\mathrm{Ag}_{2} \mathrm{O}$ (115.9 mg, $\left.0.5 \mathrm{mmol}\right),\left[(p\right.$-cymene $\left.\left.) \mathrm{RuCl}_{2}\right)\right]_{x}(306.2 \mathrm{mg}, 1$ $\mathrm{mmol})$, and $\mathrm{NaPF}_{6}(352.7 \mathrm{mg}, 2.1 \mathrm{mmol})$. The product was an orange microcrystalline solid. Yield: $549.1 \mathrm{mg}, 89 \% .{ }^{1} \mathrm{H}$ NMR (acetone- $d_{6}$, $\left.400 \mathrm{MHz}, \mathrm{SiMe}_{4}\right): \delta 9.30\left(\mathrm{~d},{ }^{3} \mathrm{~J}_{\mathrm{HH}}=5.72 \mathrm{~Hz}, 1 \mathrm{H}, \mathrm{H}_{\text {pyridine }}\right), 7.97(\mathrm{t}$, $\left.1 \mathrm{H},{ }^{3} J_{\mathrm{HH}}=7.61 \mathrm{~Hz}, 1 \mathrm{H}, \mathrm{H}_{\text {pyridine }}\right), 7.65\left(\mathrm{~d},{ }^{3} J_{\mathrm{HH}}=7.91 \mathrm{~Hz}, 1 \mathrm{H}\right.$, $\left.\mathrm{H}_{\text {pyridine }}\right), 7.60\left(\mathrm{~d},{ }^{3} J_{\mathrm{HH}}=2.05 \mathrm{~Hz}, 1 \mathrm{H}, \mathrm{H}_{\mathrm{imid}}\right), 7.59\left(\mathrm{~d},{ }^{3} J_{\mathrm{HH}}=2.05 \mathrm{~Hz}\right.$, $\left.1 \mathrm{H}, \mathrm{H}_{\text {imid }}\right), 7.47\left(\mathrm{t},{ }^{3} J_{\mathrm{HH}}=6.74 \mathrm{~Hz}, 1 \mathrm{H}, \mathrm{H}_{\text {pyridine }}\right), 5.94\left(\mathrm{~d},{ }^{3} \mathrm{~J}_{\mathrm{HH}}=6.15\right.$ $\left.\mathrm{Hz}, 1 \mathrm{H}, \mathrm{H}_{\text {arom }}\right), 5.88\left(\mathrm{~d},{ }^{3} J_{\mathrm{HH}}=5.72 \mathrm{~Hz}, 1 \mathrm{H}, \mathrm{H}_{\text {arom }}\right), 5.75\left(\mathrm{~d},{ }^{3} \mathrm{~J}_{\mathrm{HH}}=\right.$ $\left.6.15 \mathrm{~Hz}, 1 \mathrm{H}, \mathrm{H}_{\text {arom }}\right), 5.61\left(\mathrm{~d},{ }^{2} J_{\mathrm{HH}}=15.81 \mathrm{~Hz}, 1 \mathrm{H}, \mathrm{H}_{\text {bridge }}\right), 5.58$ $\left(\mathrm{d},{ }^{3} \mathrm{~J}_{\mathrm{HH}}=6.16 \mathrm{~Hz}, 1 \mathrm{H}, \mathrm{H}_{\text {arom }}\right), 5.08\left(\mathrm{~d},{ }^{2} \mathrm{~J}_{\mathrm{HH}}=15.53 \mathrm{~Hz}, 1 \mathrm{H}, \mathrm{H}_{\text {bridge }}\right)$, $5.03\left(\mathrm{~m},{ }^{3} J_{\mathrm{HH}}=6.74,1 \mathrm{H}, \mathrm{NCH}\right), 2.85\left(\mathrm{~m},{ }^{3} J_{\mathrm{HH}}=6.74 \mathrm{~Hz}, 1 \mathrm{H}\right.$, $\left.\mathrm{CH}\left(\mathrm{CH}_{3}\right)_{2}\right), 2.19\left(\mathrm{~s}, 3 \mathrm{H}, \mathrm{CH}_{3}\right), 1.64\left(\mathrm{~d},{ }^{3} J_{\mathrm{HH}}=6.73 \mathrm{~Hz}, 3 \mathrm{H}\right.$, $\left.\mathrm{NCHCH}_{3}\right), 1.38\left(\mathrm{~d},{ }^{3} J_{\mathrm{HH}}=6.44 \mathrm{~Hz}, 3 \mathrm{H}, \mathrm{NCHCH}_{3}\right), 1.20\left(\mathrm{~d},{ }^{3} \mathrm{~J}_{\mathrm{HH}}=\right.$ $\left.7.03 \mathrm{~Hz}, 3 \mathrm{H}, \mathrm{CHCH}_{3}\right), 1.18\left(\mathrm{~d},{ }^{3} J_{\mathrm{HH}}=6.74 \mathrm{~Hz}, 3 \mathrm{H}, \mathrm{CHCH}_{3}\right)$. ${ }^{13} \mathrm{C}\left\{{ }^{1} \mathrm{H}\right\}$ NMR (acetone- $\left.d_{6}, 100 \mathrm{MHz}, \mathrm{SiMe}_{4}\right): \delta 174.09\left(\mathrm{C}_{\text {imid }} \mathrm{Ru}\right)$, 159.52 ( $\left.\mathrm{C}_{\text {pyridine }}\right), 157.30$ ( $\left.\mathrm{C}_{\text {pyridine }}\right), 140.31$ ( $\left.\mathrm{C}_{\text {pyridine }}\right), 125.59$ $\left(\mathrm{C}_{\text {pyridine }}\right), 125.26\left(\mathrm{C}_{\text {pyridine }}\right), 124.10\left(\mathrm{C}_{\text {imid }}\right), 119.78\left(\mathrm{C}_{\text {imid }}\right), 111.14$ $\left(\mathrm{C}_{\text {arom }}\right), 103.46\left(\mathrm{C}_{\text {arom }}\right), 89.95\left(\mathrm{C}_{\text {arom }}\right), 86.88\left(\mathrm{C}_{\text {arom }}\right), 85.53\left(\mathrm{C}_{\text {arom }}\right)$, $85.32\left(\mathrm{C}_{\text {arom }}\right), 54.61\left(\mathrm{CH}_{2}\right), 53.21(\mathrm{NCH}), 32.30(\mathrm{CH}), 24.39$ $\left(\mathrm{NCHCH}_{3}\right), 24.16\left(\mathrm{CHCH}_{3}\right), 24.04\left(\mathrm{NCHCH}_{3}\right), 21.07\left(\mathrm{CHCH}_{3}\right)$, 18.53 $\left(\mathrm{CH}_{3}\right)$. Anal. Calcd for $\mathrm{C}_{22} \mathrm{H}_{29} \mathrm{ClF}_{6} \mathrm{~N}_{3} \mathrm{PRu}$ C, $42.83 ; \mathrm{H}, 4.74 ; \mathrm{N}$, 6.81. Found: $\mathrm{C}, 42.71 ; \mathrm{H}, 4.58 ; \mathrm{N}, 7.01$.

Chloro $\left(\eta^{6}\right.$-p-cymene) $\left(\kappa^{2} C, N-3,4,5\right.$-trimethyl-1-(2-picolyl)imidazol-2-ylidene)ruthenium(II) Hexafluorophosphate (1c). Transmetalation was carried out in $\mathrm{CH}_{2} \mathrm{Cl}_{2}(30 \mathrm{~mL})$ with $3,4,5-$ trimethyl-1-(2-picolyl)imidazolium bromide (c; $282.18 \mathrm{mg}, 1 \mathrm{mmol}$ ), $\mathrm{Ag}_{2} \mathrm{O}$ (115.9 mg, $\left.0.5 \mathrm{mmol}\right),\left[(p\right.$-cymene $\left.\left.) \mathrm{RuCl}_{2}\right)\right]_{x}$ (306.2 mg, 1 $\mathrm{mmol})$, and $\mathrm{NaPF}_{6}(352.7 \mathrm{mg}, 2.1 \mathrm{mmol})$. The product was an orange microcrystaline solid. Yield: $573.8 \mathrm{mg}, 93 \% .{ }^{1} \mathrm{H}$ NMR (acetone- $d_{6}, 400$ $\left.\mathrm{MHz}, \mathrm{SiMe}_{4}\right): \delta 9.32\left(\mathrm{~d},{ }^{3} J_{\mathrm{HH}}=5.90 \mathrm{~Hz}, 1 \mathrm{H}, \mathrm{H}_{\text {pyridine }}\right), 8.01\left(\mathrm{t},{ }^{3} \mathrm{~J}_{\mathrm{HH}}=\right.$ $\left.7.62 \mathrm{~Hz}, 1 \mathrm{H}, \mathrm{H}_{\text {pyridine }}\right), 7.81\left(\mathrm{~d},{ }^{3} J_{\mathrm{HH}}=7.82 \mathrm{~Hz}, 1 \mathrm{H}, \mathrm{H}_{\text {pyridine }}\right), 7.50$ $\left(\mathrm{t}, 1 \mathrm{H},{ }^{3} \mathrm{~J}_{\mathrm{HH}}=6.69 \mathrm{~Hz}, 1 \mathrm{H}, \mathrm{H}_{\text {pyridine }}\right), 5.93\left(\mathrm{~d},{ }^{3} \mathrm{~J}_{\mathrm{HH}}=5.89 \mathrm{~Hz}, 1 \mathrm{H}\right.$, $\left.\mathrm{H}_{\text {arom }}\right), 5.89\left(\mathrm{~d},{ }^{3} \mathrm{~J}_{\mathrm{HH}}=6.15 \mathrm{~Hz}, 1 \mathrm{H}, \mathrm{H}_{\text {arom }}\right), 5.74\left(\mathrm{~d},{ }^{3} J_{\mathrm{HH}}=6.15 \mathrm{~Hz}\right.$, $\left.1 \mathrm{H}, \mathrm{H}_{\text {arom }}\right), 5.59\left(\mathrm{~d},{ }^{3} J_{\mathrm{HH}}=6.15 \mathrm{~Hz}, 1 \mathrm{H}, \mathrm{H}_{\text {arom }}\right), 5.52\left(\mathrm{~d},{ }^{2} J_{\mathrm{HH}}=15.63\right.$
$\left.\mathrm{Hz}, 1 \mathrm{H}, \mathrm{H}_{\text {bridge }}\right), 4.93\left(\mathrm{~d},{ }^{2} J_{\mathrm{HH}}=15.64 \mathrm{~Hz}, 1 \mathrm{H}, \mathrm{H}_{\text {bridge }}\right), 3.85(\mathrm{~s}, 3 \mathrm{H}$, $\left.\mathrm{NCH}_{3}\right), 2.84\left(\mathrm{~m},{ }^{3} J_{\mathrm{HH}}=6.92 \mathrm{~Hz}, 1 \mathrm{H}, \mathrm{CH}\right), 2.34\left(\mathrm{~s}, 3 \mathrm{H}, \mathrm{CH}_{3}\right), 2.24$ (s, $\left.3 \mathrm{H}, \mathrm{CH}_{3}\right), 2.19\left(\mathrm{~s}, 3 \mathrm{H}, \mathrm{CH}_{3}\right), 1.23\left(\mathrm{~d},{ }^{3} J_{\mathrm{HH}}=7.02 \mathrm{~Hz}, 3 \mathrm{H}\right.$, $\left.\mathrm{CHCH}_{3}\right), 1.21\left(\mathrm{~d},{ }^{3} J_{\mathrm{HH}}=6.79 \mathrm{~Hz}, 3 \mathrm{H}, \mathrm{CHCH}_{3}\right) .{ }^{13} \mathrm{C}\left\{{ }^{1} \mathrm{H}\right\} \mathrm{NMR}$ (acetone- $\left.d_{6}, 100 \mathrm{MHz}, \mathrm{SiMe}_{4}\right): \delta 172.80\left(\mathrm{C}_{\text {imid }} \mathrm{Ru}\right), 159.56\left(\mathrm{C}_{\text {pyridine }}\right)$, 157.58 ( $\left.\mathrm{C}_{\text {pyridine }}\right), 140.31$ ( $\left.\mathrm{C}_{\text {pyridine }}\right), 128.07$ ( $\left.\mathrm{C}_{\text {imid }}\right), 126.49$ ( $\left.\mathrm{C}_{\text {imid }}\right)$, 125.80 ( $\left.\mathrm{C}_{\text {pyridine }}\right), 125.28$ ( $\left.\mathrm{C}_{\text {pyridine }}\right), 112.26\left(\mathrm{C}_{\text {arom }}\right), 102.75\left(\mathrm{C}_{\text {arom }}\right)$, $89.73\left(\mathrm{C}_{\text {arom }}\right), 86.71\left(\mathrm{C}_{\text {arom }}\right), 85.62\left(\mathrm{C}_{\text {arom }}\right), 85.47\left(\mathrm{C}_{\text {arom }}\right), 51.64$ $\left(\mathrm{CH}_{2}\right), 35.50\left(\mathrm{NCH}_{3}\right), 32.13(\mathrm{CH}), 23.80\left(\mathrm{CH}_{3}\right), 21.37\left(\mathrm{CH}_{3}\right), 18.56$ $\left(\mathrm{CH}_{3}\right), 9.13\left(\mathrm{CH}_{3}\right), 8.79\left(\mathrm{CH}_{3}\right)$. Anal. Calcd for $\mathrm{C}_{22} \mathrm{H}_{29} \mathrm{ClF}_{6} \mathrm{~N}_{3} \mathrm{PRu}$ : C, 42.83; H, 4.74; N, 6.81. Found: C, 42.92; H, 4.65; N, 6.74.

Chloro $\left(\eta^{6}\right.$-p-cymene) $\left(\kappa^{2} C, N-3\right.$-mesityl-1-(2-picolyl)imidazol2-ylidene)ruthenium(II) Hexafluorophosphate (1d). Transmetalation was carried out in $\mathrm{CH}_{2} \mathrm{Cl}_{2}(30 \mathrm{~mL})$ with 3-mesityl-1-(2picolyl)imidazolium bromide (d; $328.3 \mathrm{mg}, 1 \mathrm{mmol}$ ), $\mathrm{Ag}_{2} \mathrm{O}$ (115.9 $\mathrm{mg}, 0.5 \mathrm{mmol}),\left[(p\right.$-cymene $\left.\left.) \mathrm{RuCl}_{2}\right)\right]_{x}(306.2 \mathrm{mg}, 1 \mathrm{mmol})$, and $\mathrm{NaPF}_{6}$ $(352.7 \mathrm{mg}, 2.1 \mathrm{mmol})$. The product was an orange microcrystaline solid. Yield: $630.71 \mathrm{mg}, 91 \% .{ }^{1} \mathrm{H}$ NMR (acetone- $d_{6}, 400 \mathrm{MHz}, \mathrm{SiMe}_{4}$ ): $\delta 9.47\left(\mathrm{~d},{ }^{3} J_{\mathrm{HH}}=5.80 \mathrm{~Hz}, 1 \mathrm{H}, \mathrm{H}_{\text {pyridine }}\right), 8.06\left(\mathrm{t}, 1 \mathrm{H},{ }^{3} J_{\mathrm{HH}}=7.62 \mathrm{~Hz}\right.$, $\left.1 \mathrm{H}, \mathrm{H}_{\text {pyridine }}\right), 7.82\left(\mathrm{~d}, 1 \mathrm{H},{ }^{3} \mathrm{~J}_{\mathrm{HH}}=1.83 \mathrm{~Hz}, \mathrm{H}_{\text {imid }}\right), 7.76\left(\mathrm{~d},{ }^{3} \mathrm{~J}_{\mathrm{HH}}=7.32\right.$ $\left.\mathrm{Hz}, 1 \mathrm{H}, \mathrm{H}_{\text {pyridine }}\right), 7.50\left(\mathrm{t}, 1 \mathrm{H},{ }^{3} \mathrm{~J}_{\mathrm{HH}}=6.71 \mathrm{~Hz}, 1 \mathrm{H}, \mathrm{H}_{\text {pyridine }}\right), 7.34(\mathrm{~d}$, $\left.1 \mathrm{H},{ }^{3} \mathrm{~J}_{\mathrm{HH}}=1.83 \mathrm{~Hz}, \mathrm{H}_{\text {imid }}\right), 7.15\left(\mathrm{~s}, 1 \mathrm{H}, \mathrm{H}_{\text {mesityl }}\right), 6.97\left(\mathrm{~s}, 1 \mathrm{H}, \mathrm{H}_{\text {mesityl }}\right)$, $5.94\left(\mathrm{~d},{ }^{3} J_{\mathrm{HH}}=6.10 \mathrm{~Hz}, 2 \mathrm{H}, \mathrm{H}_{\text {arom }}\right), 5.87\left(\mathrm{~d},{ }^{3} J_{\mathrm{HH}}=5.64 \mathrm{~Hz}, 1 \mathrm{H}\right.$, $\left.\mathrm{H}_{\text {arom }}\right), 5.78\left(\mathrm{~d},{ }^{2} J_{\mathrm{HH}}=15.56 \mathrm{~Hz}, 1 \mathrm{H}, \mathrm{H}_{\text {bridge }}\right), 5.56\left(\mathrm{~d},{ }^{3} J_{\mathrm{HH}}=5.80 \mathrm{~Hz}\right.$, $\left.1 \mathrm{H}, \mathrm{H}_{\text {arom }}\right), 5.51\left(\mathrm{~d},{ }^{3} \mathrm{~J}_{\mathrm{HH}}=5.19 \mathrm{~Hz}, 1 \mathrm{H}, \mathrm{H}_{\text {arom }}\right), 5.26\left(\mathrm{~d},{ }^{2} J_{\mathrm{HH}}=15.57\right.$ $\left.\mathrm{Hz}, 1 \mathrm{H}, \mathrm{H}_{\text {bridge }}\right), 2.81\left(\mathrm{~m}, 1 \mathrm{H},{ }^{3} \mathrm{~J}_{\mathrm{HH}}=7.02 \mathrm{~Hz}, \mathrm{CH}\right), 2.34\left(\mathrm{~s}, 3 \mathrm{H}, \mathrm{CH}_{3}\right)$, $2.27\left(\mathrm{~s}, 3 \mathrm{H}, \mathrm{CH}_{3}\right), 2.04\left(\mathrm{~s}, 3 \mathrm{H}, \mathrm{CH}_{3}\right), 1.70\left(\mathrm{~s}, 3 \mathrm{H}, \mathrm{CH}_{3}\right), 1.14\left(\mathrm{~d},{ }^{3} \mathrm{~J}_{\mathrm{HH}}\right.$ $\left.=7.02 \mathrm{~Hz}, 3 \mathrm{H}, \mathrm{CHCH}_{3}\right), 0.58\left(\mathrm{~d},{ }^{3} \mathrm{~J}_{\mathrm{HH}}=7.02 \mathrm{~Hz}, 3 \mathrm{H}, \mathrm{CHCH}_{3}\right)$. ${ }^{13} \mathrm{C}\left\{{ }^{1} \mathrm{H}\right\}$ NMR (acetone- $\left.d_{6}, 100 \mathrm{MHz}, \mathrm{SiMe}_{4}\right): \delta 176.68\left(\mathrm{C}_{\text {imid }} \mathrm{Ru}\right)$, 160.62 ( $\left.\mathrm{C}_{\text {pyridine }}\right), 156.93$ ( $\left.\mathrm{C}_{\text {pyridine }}\right), 140.50$ ( $\left.\mathrm{C}_{\text {pyridine }}\right), 140.03$ $\left(\mathrm{NC}_{\text {mesityl }}\right), 138.74\left(\mathrm{C}_{\text {mesityl }}\right), 136.57\left(\mathrm{C}_{\text {mesityl }}\right), 135.52\left(\mathrm{C}_{\text {mesityl }}\right)$, $130.21\left(\mathrm{C}_{\text {mesityl }}\right), 129.03\left(\mathrm{C}_{\text {mesityl }}\right), 126.17\left(\mathrm{C}_{\text {imid }}\right), 125.75\left(\mathrm{C}_{\text {pyridine }}\right)$, 125.27 ( $\left.\mathrm{C}_{\text {pyridine }}\right), 124.31\left(\mathrm{C}_{\text {imid }}\right), 109.14\left(\mathrm{C}_{\text {arom }}\right), 97.02\left(\mathrm{C}_{\text {arom }}\right), 90.93$ $\left(\mathrm{C}_{\text {arom }}\right), 90.38\left(\mathrm{C}_{\text {arom }}\right), 88.66\left(\mathrm{C}_{\text {arom }}\right), 84.36\left(\mathrm{C}_{\text {arom }}\right), 55.19\left(\mathrm{CH}_{2}\right)$, $31.92(\mathrm{CH}), 24.19\left(\mathrm{CH}_{3}\right), 20.92\left(\mathrm{CH}_{3}\right), 20.13\left(\mathrm{CH}_{3}\right), 19.82\left(\mathrm{CH}_{3}\right)$, $18.30\left(\mathrm{CH}_{3}\right), 18.22\left(\mathrm{CH}_{3}\right)$. Anal. Calcd for $\mathrm{C}_{28} \mathrm{H}_{33} \mathrm{ClF}_{6} \mathrm{~N}_{3} \mathrm{PRu}$ : C, 48.52; H, 4.80; N, 6.06. Found: C, 48.43; H, 4.86; N, 6.15.

Chloro $\left(\eta^{6}-p\right.$-cymene) $\left(\kappa^{2} C, N-3-\right.$ methyl-1-(2-picolyl)benzimidazol-2-ylidene)ruthenium(II) Hexafluorophosphate (1e). Transmetalation was carried out in $\mathrm{CH}_{2} \mathrm{Cl}_{2}(30 \mathrm{~mL})$ with 3-methyl-1-(2-picolyl)benzimidazolium bromide (e; $304.2 \mathrm{mg}, 1 \mathrm{mmol}$ ), $\mathrm{Ag}_{2} \mathrm{O}$ (115.9 mg, $\left.0.5 \mathrm{mmol}\right),\left[(p\right.$-cymene $\left.\left.) \mathrm{RuCl}_{2}\right)\right]_{x}(306.2 \mathrm{mg}, 1$ $\mathrm{mmol}$ ), and $\mathrm{NaPF}_{6}(352.7 \mathrm{mg}, 2.1 \mathrm{mmol})$. The product was an orange microcrystaline solid. Yield: $549.5 \mathrm{mg}, 86 \% .{ }^{1} \mathrm{H}$ NMR (acetone- $d_{6}, 400$ $\left.\mathrm{MHz}, \mathrm{SiMe}_{4}\right): \delta 9.34\left(\mathrm{~d},{ }^{3} \mathrm{~J}_{\mathrm{HH}}=5.86 \mathrm{~Hz}, 1 \mathrm{H}, \mathrm{H}_{\text {pyridine }}\right), 8.04\left(\mathrm{t},{ }^{3} \mathrm{~J}_{\mathrm{HH}}=\right.$ $\left.7.62 \mathrm{~Hz}, 1 \mathrm{H}, \mathrm{H}_{\text {pyridine }}\right), 7.90\left(\mathrm{~d},{ }^{3} J_{\mathrm{HH}}=7.68 \mathrm{~Hz}, 1 \mathrm{H}, \mathrm{H}_{\text {pyridine }}\right), 7.89(\mathrm{~m}$, $\left.1 \mathrm{H}, \mathrm{H}_{\text {benzimid }}\right), 7.68\left(\mathrm{~m}, 1 \mathrm{H}, \mathrm{H}_{\text {benzimid }}\right), 7.53\left(\mathrm{t}, 1 \mathrm{H},{ }^{3} \mathrm{~J}_{\mathrm{HH}}=6.86 \mathrm{~Hz}, 1 \mathrm{H}\right.$, $\left.\mathrm{H}_{\text {pyridine }}\right), 7.37\left(\mathrm{~m}, 2 \mathrm{H}, \mathrm{H}_{\text {benzimid }}\right), 6.13\left(\mathrm{~d},{ }^{2} J_{\mathrm{HH}}=16.11 \mathrm{~Hz}, 1 \mathrm{H}\right.$, $\left.\mathrm{H}_{\text {bridge }}\right), 6.10\left(\mathrm{~d},{ }^{3} J_{\mathrm{HH}}=6.15 \mathrm{~Hz}, 1 \mathrm{H}, \mathrm{H}_{\text {arom }}\right), 6.07\left(\mathrm{~d},{ }^{3} J_{\mathrm{HH}}=6.15 \mathrm{~Hz}\right.$, $\left.1 \mathrm{H}, \mathrm{H}_{\text {arom }}\right), 5.91\left(\mathrm{~d},{ }^{3} J_{\mathrm{HH}}=6.30 \mathrm{~Hz}, 1 \mathrm{H}, \mathrm{H}_{\text {arom }}\right), 5.77\left(\mathrm{~d},{ }^{3} J_{\mathrm{HH}}=6.01 \mathrm{~Hz}\right.$, $\left.1 \mathrm{H}, \mathrm{H}_{\text {arom }}\right), 5.22\left(\mathrm{~d},{ }^{2} \mathrm{~J}_{\mathrm{HH}}=15.82 \mathrm{~Hz}, 1 \mathrm{H}, \mathrm{H}_{\text {bridge }}\right), 4.22\left(\mathrm{~s}, 3 \mathrm{H}, \mathrm{NCH}_{3}\right)$, $2.91\left(\mathrm{~m},{ }^{3} J_{\mathrm{HH}}=7.03 \mathrm{~Hz}, 1 \mathrm{H}, \mathrm{CH}\right), 2.23\left(\mathrm{~s}, 3 \mathrm{H}, \mathrm{CH}_{3}\right), 1.22\left(\mathrm{~d},{ }^{3} J_{\mathrm{HH}}=7.03\right.$ $\left.\mathrm{Hz}, 3 \mathrm{H}, \mathrm{CHCH}_{3}\right), 1.19\left(\mathrm{~d},{ }^{3} \mathrm{JHH}_{\mathrm{HH}}=6.74 \mathrm{~Hz}, 3 \mathrm{H}, \mathrm{CHCH}_{3}\right) .{ }^{13} \mathrm{C}\left\{{ }^{1} \mathrm{H}\right\} \mathrm{NMR}$ (acetone- $\left.d_{6}, 100 \mathrm{MHz}, \mathrm{SiMe}_{4}\right): \delta 190.45\left(\mathrm{C}_{\text {imid }} \mathrm{Ru}\right), 158.59\left(\mathrm{C}_{\text {pyridine }}\right)$, 156.38 ( $\left.\mathrm{C}_{\text {pyridine }}\right), 140.56$ ( $\left.\mathrm{C}_{\text {pyridine }}\right), 136.31$ ( $\left.\mathrm{C}_{\text {benzimid }}\right), 134.61$ ( $\left.\mathrm{C}_{\text {benzimid }}\right)$, $125.99\left(\mathrm{C}_{\text {pyridine }}\right), 125.59\left(\mathrm{C}_{\text {pyridine }}\right), 124.38\left(\mathrm{C}_{\text {benzimid }}\right), 124.36\left(\mathrm{C}_{\text {benzimid }}\right)$, $113.56\left(\mathrm{C}_{\text {arom }}\right), 111.44\left(\mathrm{C}_{\text {benzimid }}\right), 110.99\left(\mathrm{C}_{\text {benzimid }}\right), 103.29\left(\mathrm{C}_{\text {arom }}\right), 90.57$ $\left(\mathrm{C}_{\text {arom }}\right), 87.64\left(\mathrm{C}_{\text {arom }}\right), 86.53\left(\mathrm{C}_{\text {arom }}\right), 51.16\left(\mathrm{CH}_{2}\right), 35.32\left(\mathrm{NCH}_{3}\right), 32.18$ $(\mathrm{CH}), 23.58\left(\mathrm{CH}_{3}\right), 21.53\left(\mathrm{CH}_{3}\right), 18.64\left(\mathrm{CH}_{3}\right)$. Anal. Calcd for $\mathrm{C}_{24} \mathrm{H}_{27} \mathrm{ClF}_{6} \mathrm{~N}_{3} \mathrm{PRu}: \mathrm{C}, 45.11 ; \mathrm{H}, 4.26 ; \mathrm{N}, 6.58$. Found: $\mathrm{C}, 45.02 ; \mathrm{H}$, 4.31; N, 6.64 .

Chloro $\left(\eta^{6}\right.$-p-cymene) $\left(\kappa^{2} C, N-3\right.$-methyl-1-(2-picolyl)-4,5-dichloroimidazol-2-ylidene)ruthenium(II) Hexafluorophosphate (1f). Transmetalation was carried out in $\mathrm{CH}_{2} \mathrm{Cl}_{2}(30 \mathrm{~mL})$ with 3-methyl-1-(2-picolyl)-4,5-dichloroimidazolium bromide (f; $323.0 \mathrm{mg}$, $1 \mathrm{mmol}), \mathrm{Ag}_{2} \mathrm{O}$ (115.9 mg, $\left.0.5 \mathrm{mmol}\right),\left[(p\right.$-cymene $\left.\left.) \mathrm{RuCl}_{2}\right)\right]_{x}(306.2 \mathrm{mg}$, $1 \mathrm{mmol})$, and $\mathrm{NaPF}_{6}(352.7 \mathrm{mg}, 2.1 \mathrm{mmol})$. The product was a yellow microcrystaline solid. Yield: $605.2 \mathrm{mg}, 92 \% .{ }^{1} \mathrm{H}$ NMR (acetone- $d_{6}, 400$ $\left.\mathrm{MHz}, \mathrm{SiMe}_{4}\right): \delta 9.32\left(\mathrm{~d},{ }^{3} \mathrm{~J}_{\mathrm{HH}}=5.76 \mathrm{~Hz}, 1 \mathrm{H}, \mathrm{H}_{\text {pyridine }}\right), 8.08\left(\mathrm{t},{ }^{3} J_{\mathrm{HH}}=\right.$ $\left.7.63 \mathrm{~Hz}, 1 \mathrm{H}, \mathrm{H}_{\text {pyridine }}\right), 7.90\left(\mathrm{~d},{ }^{3} \mathrm{~J}_{\mathrm{HH}}=7.76 \mathrm{~Hz}, 1 \mathrm{H}, \mathrm{H}_{\text {pyridine }}\right), 7.57(\mathrm{t}, 1 \mathrm{H}$, 
$\left.{ }^{3} J_{\mathrm{HH}}=6.70 \mathrm{~Hz}, 1 \mathrm{H}, \mathrm{H}_{\text {pyridine }}\right), 6.07\left(\mathrm{~d},{ }^{3} J_{\mathrm{HH}}=6.17 \mathrm{~Hz}, 1 \mathrm{H}, \mathrm{H}_{\text {arom }}\right), 6.02$ $\left(\mathrm{d},{ }^{3} J_{\mathrm{HH}}=6.16 \mathrm{~Hz}, 1 \mathrm{H}, \mathrm{H}_{\text {arom }}\right), 5.90\left(\mathrm{~d},{ }^{3} J_{\mathrm{HH}}=6.29 \mathrm{~Hz}, 1 \mathrm{H}, \mathrm{H}_{\text {arom }}\right), 5.77$ $\left(\mathrm{d},{ }^{3} J_{\mathrm{HH}}=5.89 \mathrm{~Hz}, 1 \mathrm{H}, \mathrm{H}_{\text {arom }}\right), 5.76\left(\mathrm{~d},{ }^{2} \mathrm{~J}_{\mathrm{HH}}=16.07 \mathrm{~Hz}, 1 \mathrm{H}, \mathrm{H}_{\text {bridge }}\right)$, $5.08\left(\mathrm{~d},{ }^{2} J_{\mathrm{HH}}=16.08 \mathrm{~Hz}, 1 \mathrm{H}, \mathrm{H}_{\text {bridge }}\right), 4.00\left(\mathrm{~s}, 3 \mathrm{H}, \mathrm{NCH}_{3}\right), 2.90(\mathrm{~m}$, $\left.{ }^{3} J_{\mathrm{HH}}=6.88 \mathrm{~Hz}, 1 \mathrm{H}, \mathrm{CH}\right), 2.22\left(\mathrm{~s}, 3 \mathrm{H}, \mathrm{CH}_{3}\right), 1.27\left(\mathrm{~d},{ }^{3} \mathrm{~J}_{\mathrm{HH}}=6.70 \mathrm{~Hz}, 3 \mathrm{H}\right.$, $\left.\mathrm{CHCH}_{3}\right), 1.21\left(\mathrm{~d},{ }^{3} \mathrm{JHH}_{\mathrm{HH}}=6.96 \mathrm{~Hz}, 3 \mathrm{H}, \mathrm{CHCH}_{3}\right) .{ }^{13} \mathrm{C}\left\{{ }^{1} \mathrm{H}\right\} \mathrm{NMR}$ (acetone- $\left.d_{6}, 100 \mathrm{MHz}, \mathrm{SiMe}_{4}\right): \delta 178.39\left(\mathrm{C}_{\text {imid }} \mathrm{Ru}\right), 159.84\left(\mathrm{C}_{\text {pyridine }}\right)$, 156.10 ( $\left.\mathrm{C}_{\text {pyridine }}\right), 140.72\left(\mathrm{C}_{\text {pyridine }}\right), 126.37\left(\mathrm{C}_{\text {pyridine }}\right), 125.88\left(\mathrm{C}_{\text {pyridine }}\right)$, $118.10\left(\mathrm{C}_{\text {imid }}\right), 117.42\left(\mathrm{C}_{\text {imid }}\right), 113.77\left(\mathrm{C}_{\text {arom }}\right), 102.23\left(\mathrm{C}_{\text {arom }}\right), 89.77$ $\left(\mathrm{C}_{\text {arom }}\right), 87.67\left(\mathrm{C}_{\text {arom }}\right), 86.62\left(\mathrm{C}_{\text {arom }}\right), 86.37\left(\mathrm{C}_{\text {arom }}\right), 52.62\left(\mathrm{CH}_{2}\right), 36.93$ $\left(\mathrm{NCH}_{3}\right), 32.05(\mathrm{CH}), 23.24\left(\mathrm{CH}_{3}\right), 21.79\left(\mathrm{CH}_{3}\right), 18.62\left(\mathrm{CH}_{3}\right)$. Anal. Calcd for $\mathrm{C}_{20} \mathrm{H}_{23} \mathrm{Cl}_{3} \mathrm{~F}_{6} \mathrm{~N}_{3} \mathrm{PRu}$ : C, 36.52; H, 3.52; N, 6.39. Found: C, 36.48; $\mathrm{H}, 3.55 ; \mathrm{N}, 6.31$.

Chloro $\left(\eta^{6}-p\right.$-cymene) $\left(\kappa^{2} C, N\right.$-3-phenyl-1-(2-picolyl)imidazol2-ylidene)ruthenium(II) Hexafluorophosphate (1g). Transmetalation was carried out in $\mathrm{CH}_{2} \mathrm{Cl}_{2}(30 \mathrm{~mL})$ with 3-phenyl-1-(2picolyl)imidazolium bromide (g; $317.2 \mathrm{mg}, 1 \mathrm{mmol}), \mathrm{Ag}_{2} \mathrm{O}$ (115.9 mg, $0.5 \mathrm{mmol}),\left[(p\right.$-cymene $\left.\left.) \mathrm{RuCl}_{2}\right)\right]_{x}(306.2 \mathrm{mg}, 1 \mathrm{mmol})$, and $\mathrm{NaPF}_{6}$ (352.7 $\mathrm{mg}, 2.1 \mathrm{mmol})$. The product was an orange microcrystaline solid. Yield: $540.32 \mathrm{mg}, 83 \% .{ }^{1} \mathrm{H}$ NMR (acetone- $d_{6}, 400 \mathrm{MHz}, \mathrm{SiMe}_{4}$ ): $\delta 9.42\left(\mathrm{~d},{ }^{3} J_{\mathrm{HH}}=5.72 \mathrm{~Hz}, 1 \mathrm{H}, \mathrm{H}_{\text {pyridine }}\right), 8.03\left(\mathrm{t}, 1 \mathrm{H},{ }^{3} J_{\mathrm{HH}}=7.62 \mathrm{~Hz}\right.$, $\left.1 \mathrm{H}, \mathrm{H}_{\text {pyridine }}\right), 7.91\left(\mathrm{~m}, 2 \mathrm{H}, \mathrm{H}_{\text {arom }}\right), 7.71\left(\mathrm{~d},{ }^{3} J_{\mathrm{HH}}=1.76 \mathrm{~Hz}, 1 \mathrm{H}, \mathrm{H}_{\text {imid }}\right)$, $7.69\left(\mathrm{~d},{ }^{3} J_{\mathrm{HH}}=7.50 \mathrm{~Hz}, 1 \mathrm{H}, \mathrm{H}_{\text {pyridine }}\right), 7.57\left(\mathrm{~m}, 3 \mathrm{H}, \mathrm{H}_{\text {arom }}\right), 7.56(\mathrm{~d}$, $\left.{ }^{3} J_{\mathrm{HH}}=1.76 \mathrm{~Hz}, 1 \mathrm{H}, \mathrm{H}_{\text {imid }}\right), 7.49\left(\mathrm{t},{ }^{3} \mathrm{~J}_{\mathrm{HH}}=6.74 \mathrm{~Hz}, 1 \mathrm{H}, \mathrm{H}_{\text {pyridine }}\right), 5.73$ $\left(\mathrm{d},{ }^{2} J_{\mathrm{HH}}=15.53 \mathrm{~Hz}, 1 \mathrm{H}, \mathrm{H}_{\text {bridge }}\right), 5.68\left(\mathrm{~d},{ }^{3} J_{\mathrm{HH}}=6.15 \mathrm{~Hz}, 1 \mathrm{H}, \mathrm{H}_{\text {arom }}\right)$, $5.60\left(\mathrm{~d},{ }^{3} J_{\mathrm{HH}}=6.15 \mathrm{~Hz}, 1 \mathrm{H}, \mathrm{H}_{\text {arom }}\right), 5.36\left(\mathrm{~d},{ }^{3} J_{\mathrm{HH}}=6.15 \mathrm{~Hz}, 1 \mathrm{H}\right.$, $\left.\mathrm{H}_{\text {arom }}\right), 5.16\left(\mathrm{~d},{ }^{2} J_{\mathrm{HH}}=15.52 \mathrm{~Hz}, 1 \mathrm{H}, \mathrm{H}_{\text {bridge }}\right), 5.04\left(\mathrm{~d},{ }^{3} J_{\mathrm{HH}}=6.15 \mathrm{~Hz}\right.$, $\left.1 \mathrm{H}, \mathrm{H}_{\text {arom }}\right), 2.45\left(\mathrm{~m},{ }^{3} \mathrm{~J}_{\mathrm{HH}}=7.03 \mathrm{~Hz}, 1 \mathrm{H}, \mathrm{CH}\right), 1.92\left(\mathrm{~s}, 3 \mathrm{H}, \mathrm{CH}_{3}\right), 1.10$ $\left(\mathrm{d},{ }^{3} J_{\mathrm{HH}}=7.03 \mathrm{~Hz}, 3 \mathrm{H}, \mathrm{CHCH}_{3}\right), 0.95\left(\mathrm{~d},{ }^{3} \mathrm{~J}_{\mathrm{HH}}=7.03 \mathrm{~Hz}, 3 \mathrm{H}\right.$, $\left.\mathrm{CHCH}_{3}\right) .{ }^{13} \mathrm{C}\left\{{ }^{1} \mathrm{H}\right\} \quad \mathrm{NMR}\left(\mathrm{CDCl}_{3}, 100 \mathrm{MHz}, \mathrm{SiMe}_{4}\right): \delta 175.10$ $\left(\mathrm{C}_{\text {imid }} \mathrm{Ru}\right), 158.74\left(\mathrm{C}_{\text {pyridine }}\right), 155.38\left(\mathrm{C}_{\text {pyridine }}\right), 139.56\left(\mathrm{C}_{\text {pyridine }}\right)$, $139.26\left(\mathrm{C}_{\mathrm{NPh}}\right), 129.59\left(\mathrm{C}_{\mathrm{Ph}}\right), 128.99\left(\mathrm{C}_{\mathrm{Ph}}\right), 128.10\left(\mathrm{C}_{\mathrm{Ph}}\right), 125.28$ $\left(\mathrm{C}_{\text {pyridine }}\right), 125.19\left(\mathrm{C}_{\text {pyridine }}\right), 124.66\left(\mathrm{C}_{\text {imid }}\right), 123.08\left(\mathrm{C}_{\text {imid }}\right), 109.52$ $\left(\mathrm{C}_{\text {arom }}\right), 101.50\left(\mathrm{C}_{\text {arom }}\right), 89.97\left(\mathrm{C}_{\text {arom }}\right), 86.24\left(\mathrm{C}_{\text {arom }}\right), 85.09\left(\mathrm{C}_{\text {arom }}\right)$, $84.30\left(\mathrm{C}_{\text {arom }}\right), 54.51\left(\mathrm{CH}_{2}\right), 31.21(\mathrm{CH}), 22.98\left(\mathrm{CHCH}_{3}\right), 21.72$ $\left(\mathrm{CHCH}_{3}\right), 18.37\left(\mathrm{CH}_{3}\right)$. Anal. Calcd for $\mathrm{C}_{25} \mathrm{H}_{27} \mathrm{ClF}_{6} \mathrm{~N}_{3} \mathrm{PRu}$ : C, 46.12; H, 4.18; N, 6.45. Found: C, 46.07; H, 4.22; N, 6.49.

Crystal Structure Analysis. Crystals of 1a,f suitable for X-ray structural determination were mounted on glass fibers and then transferred to the cold nitrogen gas stream of a Bruker Smart APEX CCD three-circle diffractometer $(T=100 \mathrm{~K})$ with a sealed-tube source and graphite-monochromated Mo K $\alpha$ radiation $(\alpha=0.71073 \AA)$ at the Servicio Central de Ciencia y Tecnología de la Universidad de Cádiz. Four sets of frames were recorded over a hemisphere of the reciprocal space by $\omega$ scans with $\delta(\omega)=0.30$ and an exposure of $10 \mathrm{~s}$ per frame. Correction for absorption was applied by scans of equivalents using the SADABS program. ${ }^{51}$ An insignificant crystal decay correction was also applied. The structures were solved by direct methods and refined on $F^{2}$ by full-matrix least squares (SHELX97) by using all unique data. ${ }^{52}$ All non-hydrogen atoms were refined anisotropically. The hydrogen atoms were included in calculated positions and treated as riding atoms. For $1 \mathrm{a}$ the $\mathrm{PF}_{6}$ anion and the chlorido ligand were found to be disordered. The $\mathrm{PF}_{6}$ anion was refined over two different orientations with complementary occupancies (the final values at convergence were 0.89 and 0.11 ). In the cation, the chloride ligand was refined in two positions with complementary occupancy factors (the final values were 0.90 and 0.10 ). The program ORTEP-3 was used for plotting. ${ }^{53}$ In the Supporting Information, Table S2 summarizes the crystal data and data collection and refinement details for 1a,f. CCDC 888193 and 888194 contain supplementary crystallographic data for this paper. Copies of the data can be obtained free of charge on application to the CCDC, 12 Union Road, Cambridge CB2 1EZ, U.K. (fax, +441223-336-033; e-mail, deposit@ccdc.cam.ac.uk).

Typical Procedure for Catalytic Transfer Hydrogenation. Ketone or imine $(2.0 \mathrm{mmol})$, catalyst $0.2 \mathrm{~mol} \%(0.004 \mathrm{mmol}) \mathrm{KOH}$ (0.2 mmol), 1,3,5-trimethoxybenzene $(0.5 \mathrm{mmol})$, and ${ }^{i} \mathrm{PrOH}(4 \mathrm{~mL})$ were placed in a $10 \mathrm{~mL}$ vial and stirred on a preheated oil bath $\left(82{ }^{\circ} \mathrm{C}\right)$. Aliquots $(0.2 \mathrm{~mL})$ were taken at fixed times, and the reaction mixture was quenched with $\mathrm{Et}_{2} \mathrm{O}(3 \mathrm{~mL})$ and filtered through a short pad of $\mathrm{SiO}_{2}$. The filtrate was subjected to GC-MS and ${ }^{1} \mathrm{H}$ NMR analysis. All data reported are an average of at least two runs.

Typical Procedure for Catalytic N-alkylation of Amines with Alcohols. Amine $(2.0 \mathrm{mmol})$, alcohol $(2.0 \mathrm{mmol})$, catalyst $0.5 \mathrm{~mol} \%$ (0.01 mmol), $\mathrm{KOH}(1 \mathrm{mmol}), 1,3,5$-trimethoxybenzene $(0.5 \mathrm{mmol})$, and toluene $(2 \mathrm{~mL})$ were placed in a $10 \mathrm{~mL}$ vial and stirred on a preheated oil bath $\left(100{ }^{\circ} \mathrm{C}\right)$ for $15 \mathrm{~h}$. Aliquots $(0.2 \mathrm{~mL})$ were taken at fixed times, and the reaction mixture was quenched in $\mathrm{Et}_{2} \mathrm{O}(3 \mathrm{~mL})$ and filtered through a short pad of $\mathrm{SiO}_{2}$. The filtrate was subjected to GC-MS and ${ }^{1} \mathrm{H}$ NMR analysis. All data reported are an average of at least two runs.

\section{ASSOCIATED CONTENT}

\section{(5) Supporting Information}

A table detailing catalytic transfer hydrogenation with higher catalyst loadings and a table and CIF files giving crystallographic data for compounds 1a,f. This material is available free of charge via the Internet at http://pubs.acs.org.

\section{AUTHOR INFORMATION}

\section{Corresponding Author}

*E-mail: pedro.valerga@uca.es (P.V.); carmen.puerta@uca.es (M.C.P.).

\section{Notes}

The authors declare no competing financial interest.

\section{ACKNOWLEDGMENTS}

We thank the Spanish MICINN (Project CTQ2010-15390) and "Junta de Andalucia" (PAI-FQM188 and Project of Excellence P08-FQM-03538) for financial support and Johnson Matthey plc for generous loans of ruthenium trichloride. F.E.F. acknowledges the Spanish MICINN for an FPI fellowship (BES-2008-006635).

\section{REFERENCES}

(1) (a) Morris, R. H. Chem. Soc. Rev. 2009, 38, 2282-2291. (b) Ikariya, T.; Blacker, J. Acc. Chem. Res. 2007, 40, 1300-1308.

(2) Salvatore, R. N.; Yoon, C. H.; Jung, K. W. Tetrahedron 2001, 57, $7785-7811$.

(3) (a) Guillena, G.; Ramón, D. J.; Yus, M. Chem. Rev. 2010, 110, 1611-1641. (b) Hamid, M. H. S. A.; Allen, C. L.; Lamb, G. W.; Maxwell, A. C.; Maytum, H. C.; Watson, A. J. A.; Williams, J. M. J. J. Am. Chem. Soc. 2009, 131, 1766-1774. (c) Burling, S.; Paine, B. M.; Nama, D.; Brown, V. S.; Mahon, M. F.; Prior, T. J.; Pregosin, P. S.; Whittlesey, M. K.; Williams, J. M. J. J. Am. Chem. Soc. 2007, 129, 1987-1995. (d) Black, P. J.; Cami-Kobeci, G.; Edwards, M. G.; Slatford, P. A.; Whittlesey, M. K.; Williams, J. M. J. Org. Biomol. Chem. 2006, 4, 116-125.

(4) (a) Díez-González, S.; Marion, N.; Nolan, S. P. Chem. Rev. 2009, 109, 3612-3676. (b) Hahn, F. E.; Jahnke, M. C. Angew. Chem., Int. Ed. 2008, 47, 3122-3172. (c) Nolan, S. P.; Clavier, H. Annu. Rep. Prog. Chem., Sect. B 2007, 103, 193-222. (d) Nolan, S. P. N-Heterocyclic Carbenes in Synthesis; Wiley-VCH: Weinheim, Germany, 2006; ISBN: 978-3-527-31400-3 . (e) Herrmann, W. A. Angew. Chem., Int. Ed. 2002, 41, 1290-1309. (f) Bourissou, D.; Guerret, O.; Gabbai, F. P.; Bertrand, G. Chem. Rev. 2000, 100, 39-91.

(5) Normand, A. T.; Cavell, K. J. Eur. J. Inorg. Chem. 2008, 27812800.

(6) (a) Cabeza, J. A.; Damonte, M.; García-Álvarez, P.; Kennedy, A. R.; Pérez-Carreño, E. Organometallics 2011, 30, 826-833. (b) Hahn, F. E.; Naziruddin, A. R.; Hepp, A.; Pape, T. Organometallics 2010, 29, 5283-5288. (c) Song, G.; Li, X.; Song, Z.; Zhao, J.; Zhang, H. Chem. Eur. J. 2009, 15, 5535-5544. (d) Lee, C.; Ke, W.; Chan, K.; Lai, C.; Hu, C.; Lee, H. Chem. Eur. J. 2007, 13, 582-591. (e) Danopoulos, A. A.; Tsoureas, N.; Macgregor, S. A.; Smith, C. Organometallics 2007, 26, 253-263. (f) Lee, H. M.; Chiu, P. L.; Zeng, J. Y. Inorg. Chim. Acta 2004, 4313-4321. 
(7) (a) Warsink, S.; Chang, I.; Weigand, J. J.; Hauwert, P.; Chen, J.; Elsevier, C. J. Organometallics 2010, 29, 4555-4561. (b) Gnanamgari, D.; Sauer, E. L. O.; Schley, N. D.; Butler, C.; Incarvito, C. D.; Crabtree, R. H. Organometallics 2009, 28, 321-325.

(8) (a) Nielsen, D. J.; Cavell, K. J.; Skelton, B. W.; White, A. H. Organometallics 2006, 25, 4850-4856. (b) Herrman, W. A.; Gooben, L. J.; Spiegler, M. J. Organomet. Chem. 1997, 547, 357-366.

(9) (a) Cross, E. D.; Bierenstiel, M. Coord. Chem. Rev. 2011, 255, 574-590. (b) Fliedel, C.; Braunstein, P. Organometallics 2010, 29, 5614-5626. (c) Fliedel, C.; Sabbatini, A.; Braunstein, P. Dalton Trans. 2010, 8820-8828. (d) Huynh, H. V.; Yeo, C. H.; Chew, Y. X. Organometallics 2010, 29, 1479-1486. (e) Wolf, J.; Labande, A.; Daran, J.; Poli, R. Eur. J. Inorg. Chem. 2007, 5069-5079.

(10) (a) Gandolfi, C.; Heckenroth, M.; Neels, A.; Laurenczy, G.; Albretch, M. Organometallics 2009, 28, 5112-5121. (b) Moore, L. R.; Cooks, S. M.; Anderson, M. S.; Schanz, H.; Griffin, S. T.; Rogers, R. D.; Kirk, M. C.; Shaughnessy, K. H. Organometallics 2006, 25, 51515158

(11) (a) Takaki, D.; Okayama, T.; Shuto, H.; Matsumoto, S.; Yamaguchi, Y.; Matsumoto, S. Dalton Trans. 2011, 1445-1447. (b) Downing, S. P.; Pogorzelec, P. J.; Danopoulos, A. A.; ColeHamilton, D. J. Eur. J. Inorg. Chem. 2009, 1816-1824. (c) Xie, L.; Sun, H.; Hu, D.; Liu, Z.; Shen, Q.; Zhang, Y. Polyhedron. 2009, 28, 2585290. (d) Wang, B.; Wang, D.; Cui, D.; Gao, W.; Tang, T.; Chen, X.; Jing, X. Organometallics 2007, 26, 3167-3172. (e) Downing, S. P.; Conde Guadaño, S.; Pugh, D.; Danopulos, A. A.; Bellabarba, R. M.; Hanton, M.; Smith, D.; Tooze, R. P. Organometallics 2007, 26, 37623770. (f) Sun, H.; Hu, D.; Wang, Y.; Shen, Q.; Zhang, Y. J. Organomet. Chem. 2007, 692, 903-907. (g) Downing, S. P.; Danopoulos, A. A. Organometallics 2006, 25, 1337-1340.

(12) (a) Makino, T.; Yamasaki, R.; Azumaya, I.; Masu, H.; Saito, S. Organometallics 2010, 29, 6291-6297. (b) Amar, H. B.; Hassine, B. B.; Fischmeister, C.; Dixneuf, P. H.; Bruneau, C. Eur. J. Inorg. Chem. 2010, 4752-4756. (c) Schneider, N.; Kruck, M.; Bellemin-Laponnaz, S.; Wadepohl, H.; Gade, L. H. Eur. J. Inorg. Chem. 2009, 493-500. (d) Schneider, N.; Bellemin-Laponnaz, S.; Wadepohl, H.; Gade, L. H. Eur. J. Inorg. Chem. 2008, 5587-5598. (e) Bellemin-Laponnaz, S.; Gade, L. H. Coord. Chem. Rev. 2007, 718-725. (f) Poyatos, M.; Maisse-François, A.; Bellemin-Laponnaz, S.; Peris, E.; Gade, L. J. Organomet. Chem. 2006, 691, 2713-2720.

(13) (a) Pažiký, M.; Loos, A.; Ferreira, M. J.; Serra, D.; Vinokurov, N.; Rominger, F.; Jäkel, C.; Hashmi, A. S. K.; Limbach, M. Organometallics 2010, 29, 4448-4458. (b) Binobaid, A.; Iglesias, M.; Beetstra, D. J.; Kariuki, B.; Dervisi, A.; Fallis, I. A.; Cavell, K. J. Dalton Trans. 2009, 7099-7112. (c) Kaufhold, O.; Hahn, F. E.; Pape, T.; Hepp, A. J. Organomet. Chem. 2008, 693, 3435-3440. (d) Veige, A. S. Polyhedron 2008, 27, 3177-3189. (e) Pugh, D.; Boyle, A.; Danopoulos, A. A. Dalton Trans. 2008, 1087-1094. (f) Baya, M.; Eguillor, B.; Esteruelas, M. A.; Oliván, M.; Oñate, E. Organometallics 2007, 26, 6556-6563. (g) Wright, J. A.; Danopoulos, A. A.; Motherwell, W. B.; Carroll, R. J.; Ellwood, S. J. Organomet. Chem. 2006, 691, 5204-5210. (h) Tulloch, A. A. D.; Danopoulos, A. A.; Kleinhez, A.; Light, M. E.; Hursthouse, M. B.; Eastham, G. Organometallics 2001, 20, 2027-2031.

(14) (a) Stylianides, N.; Danopoulos, A. A.; Tsoureas, N. J. Organomet. Chem. 2005, 690, 5948-5958. (b) Song, G.; Zhang, Y.; Li, X. Organometallics 2008, 27, 1936-1943. (c) Danopoulos, A. A.; Pugh, D.; Wright, J. A. Angew. Chem., Int. Ed. 2008, 47, 9765-9767.

(15) (a) Kascatan-Nebioglu, A.; Panzner, M. J.; Tessier, C. A.; Cannon, C. L.; Youngs, W. J. Coord. Chem. Rev. 2007, 251, 884-895. (b) Catalano, V.; Etogo, A. O. J. Organomet. Chem. 2005, 690, 60416050.

(16) (a) Tulloch, A. A. D.; Winston, S.; Danopuolos, A. A.; Eastham, G.; Hursthouse, M. B. Dalton Trans. 2003, 699-708. (b) Tulloch, A. A. D.; Danopoulos, A. A.; Tooze, R. P.; Cafferkey, S. M.; Kleinhenz, S.; Hursthouse, M. B. Chem. Commun. 2000, 1247-1248.

(17) (a) Pozo, C.; Iglesias, M.; Sánchez, F. Organometallics 2011, 30, 2180-2188. (b) Chang, W.; Chen, H.; Li, T.; Hsu, N.; Tingare, Y. S.; Li, C.; Liu, Y.; Su, C.; Li, W. Angew. Chem., Int. Ed. 2010, 49, 8161-
8164. (c) Son, S. U.; Park, K. H.; Lee, Y.; Kim, B. Y.; Choi, C. H.; Lah, M. S.; Jang, Y. H.; Jang, D.; Chung, Y. K. Inorg. Chem. 2004, 43, 68966898.

(18) (a) Benítez Junquera, L.; Puerta, M. C.; Valerga, P. Organometallics 2012, 31, 2175-2183. (b) Wang, X.; Liu, S.; Weng, L.; Jin, G. J. Organomet. Chem. 2005, 690, 2934-2940. (c) Wang, X.; Liu, S.; Jin, G. Organometallics 2004, 23, 6002-6007.

(19) Warsink, S.; M. S. van Abel, C.; Weigand, J. J.; Liu, S. T.; Elsevier, C. J. Eur. J. Inorg. Chem. 2010, 5556-5562.

(20) (a) Azua, A.; Mata, J. A.; Peris, E.; Lamaty, F.; Martines, J.; Colacino, E. Organometallics 2012, 31, 3911-3919. (b) O, W. W. N.; Lough, A. J.; Morris, R. H. Organometallics 2012, 31, 2152-2165. (c) Gnanamgari, D.; Moores, A.; Rajaseelan, E.; Crabtree, R. H. Organometallics 2007, 26, 1226-1230. (d) Miecznikowski, J. R.; Crabtree, R. H. Polyhedron 2004, 23, 2857-2872. (e) Albretch, M.; Miecznikowski, J. R.; Samuel, A.; Faller, J. W.; Crabtree, R. H. Organometallics 2002, 21, 3596-3604.

(21) (a) Guelcemal, S. Appl. Organomet. Chem. 2012, 26, 246-251. (b) Mata, J. A.; Poyatos, M.; Peris, E. Coord. Chem. Rev. 2007, 251, 841-859. (c) Albretch, M.; Crabtree, R. H.; Mata, J.; Peris, E. Chem. Commun. 2002, 32-33.

(22) (a) Yigit, B.; Yigit, M.; Oezdemir, I.; Cetinkaya, E. Transit. Met. Chem. 2012, 37, 297-302. (b) O, W. W. N.; Lough, A. J.; Morris, R. H. Chem. Commun. 2010, 8240-8242. (c) Ding, N.; Hor, T. S. A. Dalton Trans. 2010, 10179-10185. (d) O, W. W. N.; Lough, A. J.; Morris, R. H. Organometallics 2009, 28, 6755-6761. (e) Dragutan, V.; Dragutan, I.; Delaude, L.; Demonceau, A. Coord. Chem. Rev. 2007, 251, 765-794.

(23) (a) Chiyojima, H.; Sakaguchi, S. Tetrahedron Lett. 2011, 52, 6788-6791. (b) Duan, W.; Shi, M.; Rong, G. Chem. Commun. 2003, 2916-2917.

(24) (a) Nolan, S. P.; Bosson, J. J. Org. Chem. 2010, 75, 2039-2043. (b) Coberán, R; Peris, E. Organometallics 2008, 27, 1954-1958. (c) Marr, A. C.; Pollock, C. L.; Saunders, G. C. Organometallics 2007, 26, 3283-3285. (d) Huang, J.; Jafarpour, L.; Hillier, A. C.; Stevens, E. D.; Nolan, S. P. Organometallics 2001, 20, 2878-2882. (e) Huang, J.; Stevens, E. D.; Nolan, S. P.; Petersen, J. L. J. Am. Chem. Soc. 1999, 121, 2674-2678.

(25) Fernández, F. E.; Puerta, M. C.; Valerga, P. Organometallics 2011, 30, 5793-5802.

(26) Prades, A.; Corberán, R.; Poyatos, M.; Peris, E. Chem. Eur. J. 2008, 14, 11474-11479.

(27) (a) Gnanaprakasam, B.; Zhang, J.; Milstein, D. Angew. Chem., Int. Ed. 2010, 49, 1468-1471. (b) Dobereiner, G. E.; Crabtree, R. H. Chem. Rev. 2010, 110, 681-703. (c) Blank., B.; Madalska, M.; Kempe, R. Adv. Synth. Catal. 2008, 350, 749-758. (d) Hamid, M. H. S. A.; Williams, J. M. J. Chem. Commun. 2007, 725-727. (e) Hollmann, D.; Tillack, A.; Michalik, D.; Jackstell, R.; Beller, M. Chem. Asian J. 2007, 2, 403-410. (f) Naskar, S.; Bhattacharjee, M. Tetrahedron Lett. 2007, 48, 3367-3370. (g) Del Zotto, A.; Baratta, W.; Sandri, M.; Verardo, G.; Rigo, P. Eur. J. Inorg. Chem. 2004, 524-529. (h) Watanabe, Y.; Morisaki, Y.; Kondo, T.; Mitsudo, T. J. Org. Chem. 1996, 61, 42144218. (i) Ganguly, S.; Roundhill, D. M. Polyhedron. 1990, 9, 25172526. (j) Watanabe, Y.; Tsuji, Y.; Ige, H.; Ohsugi, Y.; Ohta, T. J. Org. Chem. 1984, 49, 3359-3363. (k) Murahashi, S.; Kondo, K.; Hakata, T. Tetrahedron Lett. 1982, 23, 229-232. (1) Grigg, R.; Mitchel, T. R. B.; Sutthivaiyakit, S.; Tongpenyai, N. J. Chem. Soc., Chem. Commun. 1981, 611-612.

(28) McGuinness, D. S.; Cavell, K. J. Organometallics 2000, 19, 741748

(29) Gruendemann, S.; Kovacevic, A.; Albrecht, M.; Faller, J. W.; Crabtree, R. H. J. Am. Chem. Soc. 2002, 124, 10473-10481.

(30) Jahnke, M. C.; Pape, T.; Hahn, F. E. Eur. J. Inorg. Chem. 2009, 1960-1969.

(31) Tulloch, A. A. D.; Danopoulos, A. A.; Winston, S.; Kleinhenz, S.; Eastham, G. Dalton Trans. 2000, 4499-4506.

(32) Wang, X.; Liu, S.; Weng, L.; Jin, G. Chem. Eur. J. 2007, 13, 188195. 
(33) Herrmann, W. A.; Elison, M.; Fisher, J.; Kocher, C.; Artus, G. R. J. Chem. Eur. J. 1996, 2, 772-780.

(34) Cheng, Y.; Xu, H.; Sun, J.; Li, Y.; Chen, X.; Xue, Z. Dalton Trans. 2009, 7132-7140.

(35) (a) Liu, X.; Chen, W. Dalton Trans. 2012, 41, 599-608. (b) Ghattas, W.; Muller-Bunz, H.; Albrecht, M. Organometallics 2010, 29, 6782-6789. (c) Zhang, Y.; Chen, C.; Ghosh, S. C.; Li, Y.; Hong, S. H. Organometallics 2010, 29, 1374-1378.

(36) Duan, G.; Wong, W.; Yam, V. W. New J. Chem. 2011, 35, 22672278.

(37) (a) Wittcoff, H. A.; Reuben, B. G.; Plotkin, J. S. Industrial Organic Chemicals; Wiley-Interscience: New York, 2004; ISBN: 978-0471-44385-8. (b) Hayes, K. S. Appl. Catal. A 2001, 221, 187-195. c Pharmaceuticals: Classes, Therapeutic Agents, Areas of Applications; McGuire, J. L., Ed.; Wiley-VCH: Weinheim, Germany, 2000; ISBN: 978-3-527-29874-7. (d) Wittcoff, H. A.; Reuben, B. G. Pharmaceuticals Chemicals in Perspective; .Wiley-Interscience: New York, 1990; ISBN: 978-0-471-84363-4.

(38) Prades, A.; Peris, E.; Albretch, M. Organometallics 2011, 30, $1162-1167$.

(39) (a) Xu, C.; Goh, L. Y.; Pullarkat. Organometallics 2011, 30, 6499-6502. (b) Esteruelas, M. A.; Honczek, N.; Oliván, M.; Oñate, E.; Valencia, M. Organometallics 2011, 30, 2468-2471. (c) Kegnæs, S.; Mielby, J.; Mentzel, U. V.; Christensen, C.; Riisager, A. Green Chem. 2010, 12, 1437-1441. (d) Sun, H.; Su, F.; Ni, J.; Cao, Y.; He, H.; Fan, K. Angew. Chem., Int. Ed. 2009, 48, 4390-4393.

(40) Fujita, K.; Enoki, Y.; Yamaguchi, R. Tetrahedron 2008, 64, $1943-1954$

(41) Cano, R.; Ramón, D. J.; Yus, M. J. Org. Chem. 2011, 76, 55475557.

(42) Nordstrøm, L. U.; Vogt, H.; Madsen, R. J. Am. Chem. Soc. 2008, 130, 17672-17673.

(43) (a) Nova, A.; Balcells, D.; Schley, N. D.; Dobereiner, G. E.; Crabtree, R. H.; Eisenstein, O. Organometallics 2010, 29, 6548-6558. (b) Ghosh, S. C.; Muthaiah, S.; Zhang, Y.; Xu, X.; Hong, S. H. Adv. Synth. Catal. 2009, 351, 2643-2649. (c) Gunanathan, C.; Ben-David, Y.; Milstein, D. Science 2007, 317, 790-792.

(44) (a) Du, W.; Wang, L.; Wu, P.; Yu, Z. Chem. Eur. J. 2012, 18, 11550-11554. (b) Watson, A. J. A.; Maxwell, A. C.; Williams, J. M. J. Org. Lett. 2009, 11, 2667-2670. (c) Yamakawa, M.; Ito, H.; Koyori, R. J. Am. Chem. Soc. 2000, 122, 1466-1478.

(45) (a) Gürbüz, N.; Özcan, E. Ö.; Özdemir, I.; Çetinkaya, B.; Şahin, O.; Büyünkgüngör. Dalton Trans. 2012, 41, 2330-2339. (b) Horn, S.; Gandolfi, C.; Albretch, M. Eur. J. Inorg. Chem. 2011, 2863-2868. (c) Cross, W. B.; Daly, C. G.; Boutadla, Y.; Singh, K. Dalton Trans. 2011, 40, 9722-9730. (d) Li, X.; Wang, G.; Chen, F.; Chen, X.; Xue, Z. Inorg. Chim. Acta 2011, 379, 280-287. (e) Sinha, A.; Daw, P.; Rahaman, S. M. W.; Saha, B.; Bera, J. K. J. Organomet. Chem. 2011, 696, 1248-1257. (f) Monney, A.; Venkatachalam, G.; Albretch, M. Dalton Trans. 2011, 40, 2716-2719. (g) Cheng, Y.; Sun, J.; Yang, H.; Xu, H.; Li, Y.; Chen, X.; Xue, Z. Organometallics 2009, 28, 819-823.

(h) Zeng, F.; Yu, Z. Organometallics 2008, 27, 6025-6028. (i) Chiu, P. L.; Lee, H. M. Organometallics 2005, 24, 1692-1702.

(46) Ohara, H.; W. N. O., W.; Lough, A. J.; Morris, R. H. Dalton Trans. 2012, 41, 8797-8808.

(47) Pàmies, O.; Bäckvall, J. Chem. Eur. J. 2001, 7, 5052-5058.

(48) Samec, J: S.; Backvall, J.; Andersson, P.; Brandt, P. Chem. Soc. Rev. 2006, 35, 237-248.

(49) Bennet, M. A.; Smith, A. K. J. Chem. Soc., Dalton Trans. 1974, 233-241.

(50) Bahr, S. R.; Boudjouk, P. J. Org. Chem. 1992, 57, 5545-5547.

(51) Sheldrick, G. M. SADABS, 2001 version; University of Göttingen, Göttingen, Germany, 2001.

(52) (a) Sheldrick, G. M.SHELXTL version 6.10, Crystal Structure Analysis Package; Bruker AXS, Madison, WI, 2000. (b) Sheldrick, G. M. Acta Crystallogr. 2008, A64, 112-122.

(53) Farrugia, L. J. ORTEP-3 for Windows, version 1.076. J. Appl. Crystallogr. 1997, 30, 565. 